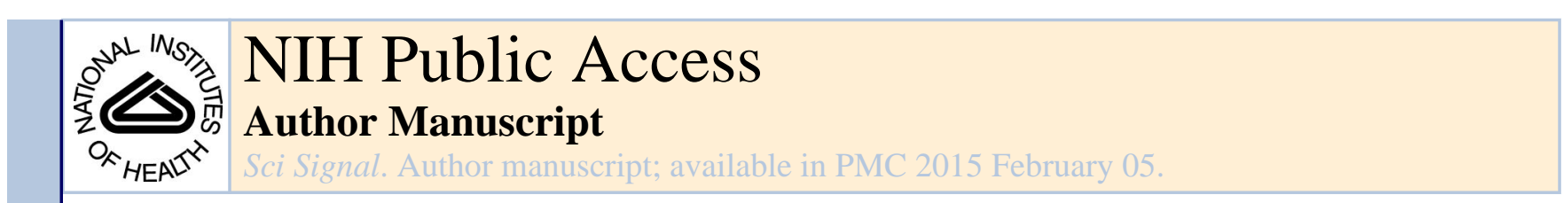

Published in final edited form as:

Sci Signal. ; 7(337): ra74. doi:10.1126/scisignal.2005147.

\title{
Calmodulin and $\mathrm{PI}(3,4,5) \mathrm{P}_{3}$ Cooperatively Bind to the Itk Pleckstrin Homology Domain to Promote Efficient Calcium Signaling and IL-17A Production
}

\author{
Xinxin Wang ${ }^{1, \dagger}$, Scott E. Boyken ${ }^{2, \dagger}$, Jiancheng $\mathrm{Hu}^{1}$, Xiaolu $\mathrm{Xu}^{1}$, Ryan P. Rimer ${ }^{1}$, Madeline \\ A. Shea ${ }^{3}$, Andrey S. Shaw ${ }^{1}$, Amy H. Andreotti ${ }^{2}$, and Yina H. Huang ${ }^{1,4,5}{ }^{*}$ \\ ${ }^{1}$ Department of Pathology and Immunology, Washington University, St. Louis, MO 63110 \\ ${ }^{2}$ Department of Biochemistry, Biophysics and Molecular Biology, lowa State University, Ames, IA \\ 50011 \\ ${ }^{3}$ Department of Biochemistry, University of lowa, lowa City, IA 52242 \\ ${ }^{4}$ Department of Pathology, The Geisel School of Medicine at Dartmouth, Lebanon, NH 03756 \\ ${ }^{5}$ Department of Microbiology \& Immunology, The Geisel School of Medicine at Dartmouth, \\ Lebanon, NH 03756
}

\section{Abstract}

Precise regulation of the kinetics and magnitude of $\mathrm{Ca}^{2+}$ signaling enables this signal to mediate diverse responses, such as cell migration, differentiation, vesicular trafficking, and cell death. Here, we showed that the $\mathrm{Ca}^{2+}$-binding protein calmodulin $(\mathrm{CaM})$ acted in a positive feedback loop to potentiate $\mathrm{Ca}^{2+}$ signaling downstream of the Tec kinase family member Itk. Using NMR (nuclear magnetic resonance), we mapped CaM binding to two loops adjacent to the lipid-binding pocket within the Itk pleckstrin homology $(\mathrm{PH})$ domain. The Itk $\mathrm{PH}$ domain bound synergistically to $\mathrm{Ca}^{2+} / \mathrm{CaM}$ and the lipid phosphatidylinositol-3,4,5-trisphosphate [PI(3,4,5)P3], such that binding to $\mathrm{Ca}^{2+} / \mathrm{CaM}$ enhanced the binding to $\mathrm{PI}(3,4,5) \mathrm{P}_{3}$ and vice versa. Disruption of $\mathrm{CaM}$ binding attenuated Itk recruitment to the membrane and diminished release of $\mathrm{Ca}^{2+}$ from the endoplasmic reticulum. Moreover, disruption of this feedback loop abrogated Itk-dependent production of the proinflammatory cytokine IL-17A (interleukin-17A) by $\mathrm{CD}^{+}{ }^{+} \mathrm{T}$ cells.

Additionally, we found that $\mathrm{CaM}$ associated with $\mathrm{PH}$ domains from other proteins, indicating that $\mathrm{CaM}$ may regulate other $\mathrm{PH}$ domain-containing proteins.

*Correspondence to: Y.H.H. (Yina.H.Huang@ dartmouth.edu). Departments of Pathology and Microbiology and Immunology, The Geisel School of Medicine at Dartmouth HB 7600, Borwell 604E One Medical Center Drive Lebanon, NH 03756 Phone: (603)650-7545.

$\dagger$ These authors contributed equally to this work.

Author contributions: X.W. and Y.H.H. conceived the study. X.W. performed the biochemical and functional experiments. S.E.B. performed and analyzed the NMR studies. M.A.S. and A.H.A. analyze the NMR studies. J.H. and A.S.S. helped with imaging. X.X. analyzed confocal micrographs. X.W., S.E.B., M.A.S., A.H.A. and Y.H.H. prepared the manuscript.

Competing interests: The authors declare no competing interests. 


\section{Introduction}

The pleckstrin homology (PH) domain is a beta barrel formed by two antiparallel $\beta$ sheets and a C-terminal amphipathic helix and was initially identified over 20 years ago as a repeated domain in the protein Pleckstrin (1). Since its discovery, PH domains have been recognized in proteins from bacteria to mammals $(2,3)$. Several hundred mammalian proteins that participate in diverse cellular functions contain one or multiple $\mathrm{PH}$ domains. PH domains are generally recognized as membrane-targeting domains $(4,5)$; although these domains may have other functions as well. Lipid-binding PH domains have positively charged residues in the loops between specific $\beta$ strands $(\beta 1 / \beta 2, \beta 3 / \beta 4$, and $\beta 6 / \beta 7)$ and these charged residues differentially interact with negatively charged lipids, including phosphoinositides, such as phosphatidylinositol-4-phosphate [PI4P], phosphatidylinositol-4,5-bisphosphate $\left[\mathrm{PI}(4,5) \mathrm{P}_{2}\right]$, phosphatidylinositol-3,4-bisphosphate $\left[\mathrm{PI}(3,4) \mathrm{P}_{2}\right]$, and phosphatidylinositol-3,4,5-trisphosphate $\left[\mathrm{PI}(3,4,5) \mathrm{P}_{3}\right](1)$. Although most lipid-binding PH domains interact weakly or promiscuously with a range of lipid targets, a few PH domains have high specificity and submicromolar affinity for specific phospholipids (1). Among these, the PH domains of Akt and Tec family kinases interact with $\mathrm{PI}(3,4,5) \mathrm{P}_{3}$, a plasma membrane phospholipid that is generated by phosphatidylinositol -3 kinase (PI3K) following receptor activation (6). The Akt family of serine/threonine kinases promotes survival and proliferation in most cell types. The Tec family of tyrosine kinases is critical for the development and activation of immune cells. Mutations in the PH domain of the Tec kinase Bruton's tyrosine kinase (Btk) that disrupt $\mathrm{PI}(3,4,5) \mathrm{P}_{3}$ binding result in defective $\mathrm{B}$ cell responses, causing a primary immunodeficiency disease known as X-linked agammaglobulinaemia (XLA) in humans and X-linked immunodeficiency (Xid) in mice (7, 8). In contrast, a Btk mutant (E41K) that increases the association of the PH domain with phospholipids is constitutively active and has cellular transforming activity (9).

Mutation in humans or gene targeting in mice of the Tec kinase IL-2 inducible tyrosine kinase (Itk) disrupts T cell function, resulting in primary immunodeficiency disease $(10,11)$. Itk-deficient mice fail to mount a protective $\mathrm{T}$ helper type $2\left(\mathrm{~T}_{\mathrm{H}} 2\right)$ response to parasites, including Nippostrongylus brasiliensis, Schistosoma mansoni, and Leishmania major (12, 13). Itk activity is required for optimal $\mathrm{T}$ cell activation and expansion; Itk-deficient $\mathrm{T}$ cells ultimately fail to provide immune protection due to insufficient production of the cytokine interleukin 4 (IL-4) due to reduced activation of the transcription factor NFATc (12). Similarly, NFATc-dependent production of the pro-inflammatory cytokine IL-17A is also disrupted in Itk-deficient T cells (14). Optimal IL-17A depends on maximal signaling by the $\mathrm{T}$ cell receptor (TCR) and Itk activation in particular (14). Given the importance of IL-17A in promoting contact hypersensitivity, collagen-induced arthritis, and experimental autoimmune encephalomyelitis (15), targeting Itk pharmacologically may ameliorate some $\mathrm{T}$ cell-mediated autoimmune diseases.

Tec kinases promote cellular responses by activating phospholipase $\mathrm{C} \gamma$ (PLC $\gamma$ ) to generate the second messengers, diacylglycerol (DAG) and inositol 1,4,5-trisphosphate $\left(\mathrm{IP}_{3}\right)(10,11)$. $\mathrm{IP}_{3}$ production triggers $\mathrm{Ca}^{2+}$ signaling $(16,17)$. Cytosolic $\mathrm{Ca}^{2+}$ concentrations in resting cells are maintained at a low concentration, typically $100 \mathrm{nM}$, by actively pumping free $\mathrm{Ca}^{2+}$ into the endoplasmic reticulum (ER) and into the extracellular space where $\mathrm{Ca}^{2+}$ 
concentrations are in the $\mathrm{mM}$ range (16). $\mathrm{IP}_{3}$ binding to $\mathrm{IP}_{3}$ receptors on the ER triggers release of ER-stored $\mathrm{Ca}^{2+}$ and subsequent $\mathrm{Ca}^{2+}$ influx from the extracellular environment through store-operated plasma membrane channels. The large $\mathrm{Ca}^{2+}$ concentration differential present in resting cells provides a powerful and rapid mechanism to activate cellular responses through regulation of cytosolic $\mathrm{Ca}^{2+}$ concentrations.

$\mathrm{Ca}^{2+}$ directly alters the activity of proteins by binding to $\mathrm{C} 2$ and $\mathrm{EF}$ hand domains (16). $\mathrm{Ca}^{2+}$ also indirectly activates effectors by regulating the conformation of the evolutionarily conserved allosteric regulator calmodulin $(\mathrm{CaM}) . \mathrm{Ca}^{2+}$ binding to the four $\mathrm{EF}$ hands of $\mathrm{CaM}$ (defined as $\mathrm{Ca}^{2+} / \mathrm{CaM}$ ) promotes its association with many cellular enzymes and ion channels, leading to their activation or deactivation (16). $\mathrm{Ca}^{2+} / \mathrm{CaM}$-dependent effectors include myosin light chain kinase (MLCK), CaM kinases, and calcineurin, which induce myosin-dependent cellular contraction, cellular differentiation, and NFAT-dependent gene transcription, respectively.

Here, we investigated whether CaM bound and regulated the $\mathrm{PI}(3,4,5) \mathrm{P}_{3}$-binding $\mathrm{PH}$ domains of the Tec family kinases. We found that $\mathrm{Ca}^{2+} / \mathrm{CaM}$ binds to Itk, but not the related Tec kinase Btk. To examine the interaction between $\mathrm{Ca}^{2+} / \mathrm{CaM}$ and Itk further, we used nuclear magnetic resonance (NMR) spectroscopy to map CaM binding to two loops within the Itk $\mathrm{PH}$ domain that are adjacent to the lipid-binding pocket. $\mathrm{Ca}^{2+} / \mathrm{CaM}$ and $\mathrm{PI}(3,4,5) \mathrm{P}_{3}$ cooperated to enhance binding to either ligand. Disruption of $\mathrm{Ca}^{2+} / \mathrm{CaM}$ binding attenuated Itk recruitment to the membrane and subsequent activation of PLC $\gamma 1$, indicating that $\mathrm{Ca}^{2+} / \mathrm{CaM}$ binding to the Itk PH domain acts in a positive feedback loop to potentiate and sustain $\mathrm{Ca}^{2+}$ signaling. Disruption of this feedback loop abrogated Itk-dependent production of the pro-inflammatory cytokine IL-17A by $\mathrm{CD} 4^{+} \mathrm{T}$ cells. Moreover, we present data that $\mathrm{Ca}^{2+} / \mathrm{CaM}$ may be a general binding partner and potential regulator of other proteins with PH domains.

\section{Results}

\section{$\mathrm{Ca}^{2+} / \mathrm{CaM}$ binds to the Itk PH domain but not the Btk PH domain}

To test whether $\mathrm{CaM}$ interacts with the Tec kinases Itk and Btk, we incubated mouse splenocyte lysates with CaM-coated beads and assessed the presence of endogenous Itk or Btk in the precipitated samples by Western blot(Fig. 1A). As a positive control, we coprecipitated both kinases using $\mathrm{PI}(3,4,5) \mathrm{P}_{3}$-coated beads. Both Tec kinases bound to the phospholipid ligand; however, only Itk interacted with $\mathrm{CaM}$ and more Itk was present in the precipitates as the concentration of $\mathrm{Ca}^{2+}$ was increased in the precipitation buffer. Coprecipitation experiments with yellow fluorescent protein (YFP) fused to either fulllength Itk or the with the PH domain of Itk showed that the PH domain of Itk mediated the interaction with $\mathrm{CaM}$ (fig. S1). We further characterized the interaction using recombinant Itk PH domain generated and purified from bacteria and CaM. The isolated Itk PH domain bound directly to $\mathrm{CaM}$ in a $\mathrm{Ca}^{2+}$-dependent manner; a $\mathrm{Ca}^{2+}$ concentration of $1 \mu \mathrm{M}$ was used to mimic cytosolic $\mathrm{Ca}^{2+}$ concentrations in activated $\mathrm{T}$ cells (Fig. 1B). The presence of the $\mathrm{Ca}^{2+}$-chelator EGTA reduced the interaction between $\mathrm{CaM}$ and the Itk PH domain (Fig. 1B). 


\section{$\mathrm{PI}(3,4,5) \mathrm{P}_{3}$ promotes CaM binding to the Itk $\mathrm{PH}$ domain}

Because Itk activation requires $\mathrm{PH}$ domain-mediated recruitment to the membrane by $\mathrm{PI}(3,4,5) \mathrm{P}_{3}$, we investigated the effect of $\mathrm{PI}(3,4,5) \mathrm{P}_{3}$ binding on the Itk $\mathrm{PH}$ domain interaction with $\mathrm{CaM}$ by adding soluble phosphatidylinositides to the cellular lysates during CaM precipitation. Remarkably, $\mathrm{PI}(3,4,5) \mathrm{P}_{3}$, but not $\operatorname{Ins}(1,3,4,5) \mathrm{P}_{4}$ [a physiological mimic of the $\mathrm{PI}(3,4,5) \mathrm{P}_{3}$ head group] or its membrane precursor $\mathrm{PI}(4,5) \mathrm{P}_{2}$, enhanced $\mathrm{CaM}$ binding to endogenous Itk in a dose-dependent manner (Fig. 1C and D). These data indicated that both $\mathrm{Ca}^{2+}$ and $\mathrm{PI}(3,4,5) \mathrm{P}_{3}$ enhanced the binding of the Itk PH domain to $\mathrm{CaM}$.

\section{Structural characterization of the Itk PH-CaM binding interface}

We used NMR spectroscopy to identify the specific residues in both CaM and the Itk PH domain that mediate the interaction. We measured the resonance frequencies of each amide $\mathrm{N}-\mathrm{H}$ group in the protein (either $\mathrm{CaM}$ or the C96E/T110I Itk PH domain variant, which facilitates PH domain solubilization (18)) using the ${ }^{1} \mathrm{H}-{ }^{15} \mathrm{~N}$ Heteronuclear Single Quantum Correlation (HSQC) spectrum and assigned the backbone $\mathrm{N}-\mathrm{H}$ resonances of $\mathrm{CaM}$ using data from the Biological Magnetic Resonance Data Bank (BMRB) and assigned the backbone N-H resonances for the Itk PH domain using the standard suite of triple-resonance NMR experiments (see Materials and Methods).

We then added the unlabeled Itk PH domain to ${ }^{15} \mathrm{~N}$-labeled CaM (Fig. 2A) or unlabeled $\mathrm{CaM}$ to the ${ }^{15} \mathrm{~N}$-labeled Itk PH domain (Fig. 2B). The spectral changes in both titrations revealed extensive line broadening upon addition of increasing concentrations of binding partner (Fig. 2A and B). Such line broadening can be ascribed to the size of the CaM-Itk PH complex, can indicate a protein-protein interaction that is undergoing intermediate exchange on the NMR timescale, or can result from both. A subset of the CaM and Itk PH domain resonances showed pronounced spectral changes upon addition of small amounts of binding partner (Fig. 2A and B) consistent with formation of a specific complex. Mapping of the residues that correspond to these resonances onto a structure of $\mathrm{Ca}^{2+} / \mathrm{CaM}(19)$ and a model of the Itk PH domain (see Materials and Methods) revealed that these residues cluster to contiguous regions on the tertiary structure of each domain (Fig. 3A and B). In $\mathrm{Ca}^{2+} / \mathrm{CaM}$, the residues showing the largest spectral shift occur in both the $\mathrm{N}$ - and C-domains (Fig. 2A and $3 \mathrm{~A}$ ). The region of the Itk PH domain involved in the interaction with $\mathrm{Ca}^{2+} / \mathrm{CaM}$ includes the $\beta 3 / \beta 4$ and $\beta 5 / \beta 6$ loops, the adjacent $\beta$-strands 2,3 and 4 and portions of $\beta 1$ and $\beta 5$ (Fig. 3B). These regions of the Itk PH domain are adjacent to and not overlapping with the $\mathrm{PI}(3,4,5) \mathrm{P}_{3}$ binding pocket (Fig. $3 \mathrm{~B}$ and $\mathrm{C}$ ), consistent with an allosteric mechanism for $\mathrm{PI}(3,4,5) \mathrm{P}_{3}$ enhancement of $\mathrm{CaM}$ binding (Fig. $1 \mathrm{C}$ and $\mathrm{D}$ ).

The Itk PH domain also binds apo-CaM $\left(\mathrm{Ca}^{2+}\right.$ free calmodulin), albeit much more weakly (Fig. 4A). Compared to the NMR titration with $\mathrm{Ca}^{2+} / \mathrm{CaM}$ (Fig. 2A), addition of the unlabeled Itk PH domain to ${ }^{15} \mathrm{~N}$-labeled apo-CaM produced less extensive line broadening even at much higher concentrations, and spectral changes were observed for only a small subset of CaM resonances, the majority of which localize to the CaM C-domain when mapped onto the structure (20) (Fig. 4B). Consistent with this observation, the NMR analysis indicated that the same residues that showed the largest shifts in the $\mathrm{Ca}^{2+} / \mathrm{CaM} \mathrm{C}$ - 
domain fragment in the presence of the Itk PH domain (Fig. 4C) also shifted, albeit to a lesser extent, in the apo form of the CaM C-domain bound to the Itk PH domain (Fig. 4D).

The spectral changes that occurred upon addition of the isolated CaM C-domain $\left(\mathrm{Ca}^{2+}\right.$ bound or apo) to the Itk PH domain were restricted to the $\beta$-strands 2,3 , and 4 and the $\beta 3 / \beta 4$ loop in the Itk PH domain (Fig. 3B). The region of the Itk PH domain that encompasses the $\beta 5 / \beta 6$ loop and $\beta$-strand 5 only showed spectral changes on titration of $\mathrm{Ca}^{2+} / \mathrm{CaM}$. Regardless of the presence or absence of $\mathrm{Ca}^{2+}$, the CaM N-domain fragment by itself and the Itk PH domain did not interact (fig. S2). Thus, the CaM C-domain and the region surrounding the $\beta 3 / \beta 4$ loop in the Itk PH domain seem to be most critical in mediating the interaction between $\mathrm{CaM}$ and the Itk PH domain.

\section{CaM promotes Itk activity and amplifies $\mathrm{Ca}^{2+}$ signaling through a positive feedback loop}

TCR stimulation promotes increased association of endogenous Itk from cellular lysates with $\mathrm{PI}(3,4,5) \mathrm{P}_{3}$-coated beads in vitro (21) and recruitment to the immune synapse in $T$ cells (22). We, therefore, asked whether CaM is necessary for TCR-induced Itk binding to $\mathrm{PI}(3,4,5) \mathrm{P}_{3}$. We stimulated purified $\mathrm{T}$ cells with antibodies that crosslink surface $\mathrm{CD} 3$ and $\mathrm{CD} 4$ receptors in the presence or absence of W-7, an inhibitor of $\mathrm{Ca}^{2+} / \mathrm{CaM}(23)$, and compared the binding of endogenous Itk from cell lysates to $\mathrm{PI}(3,4,5) \mathrm{P}_{3}$-coated beads. Pharmacologic inhibition of CaM with W-7 reduced basal and TCR-induced binding of endogenous Itk from $\mathrm{T}$ cell lysates to $\mathrm{PI}(3,4,5) \mathrm{P}_{3}$-coated beads, indicating that $\mathrm{CaM}$ enhanced $\mathrm{PI}(3,4,5) \mathrm{P}_{3}$ binding (Fig. 5A). Consistent with decreased Itk membrane recruitment and activity, Itk-mediated phosphorylation of PLC $\gamma 1$ was also decreased by W-7 (Fig. 5A). However, activity of the upstream kinase Lck was unaffected by CaM inhibition (Fig. 5A). Together, these data indicated that $\mathrm{CaM}$ and $\mathrm{PI}(3,4,5) \mathrm{P}_{3}$ cooperatively promoted Itk-mediated PLC $\gamma 1$ phosphorylation in response to TCR stimulation.

By hydrolyzing PI(4,5) $\mathrm{P}_{2}, \mathrm{PLC} \gamma 1$ generates the second messengers, $\mathrm{DAG}$ and $\mathrm{IP}_{3} . \mathrm{IP}_{3}$ stimulates $\mathrm{Ca}^{2+}$ release from the ER by binding to $\mathrm{IP}_{3}$ receptors, which are ligand-activated $\mathrm{Ca}^{2+}$ channels. To determine whether optimal Itk-dependent $\mathrm{Ca}^{2+}$ release requires $\mathrm{CaM}$, we measured cytosolic $\mathrm{Ca}^{2+}$ signals with a ratiometric $\mathrm{Ca}^{2+}$-indicator dye in primary mouse thymocytes exposed to W-7. W-7, but not vehicle or the nonfunctional analog W-12, diminished TCR-induced $\mathrm{Ca}^{2+}$ release from the ER (Fig. 5B). As a control for equal loading of the $\mathrm{Ca}^{2+}$-indicator dye and equivalent $\mathrm{Ca}^{2+}$ levels in the stores, thymocytes were treated with the ionophore, Ionomycin (Ion). Vehicle, W-7 and W-12 treatment had little effect on Ionomycin-induced $\mathrm{Ca}^{2+}$ release from the ER stores (Fig. 5B). These data support a positive feedback role for $\mathrm{Ca}^{2+} / \mathrm{CaM}$ in promoting Itk membrane recruitment and triggering of downstream $\mathrm{Ca}^{2+}$ signals.

To further evaluate the positive feedback of $\mathrm{Ca}^{2+}$ on Itk activity, we assessed the effect of depleting total intracellular $\mathrm{Ca}^{2+}$ with BAPTA-AM treatment and inhibiting PLC $\gamma 1$ activity on Itk activity. BAPTA-mediated $\mathrm{Ca}^{2+}$ depletion reduced Itk binding to $\mathrm{PI}(3,4,5) \mathrm{P}_{3}$ and PLC $\gamma 1$ phosphorylation (Fig. 5C). Inhibition of PLC $\gamma 1$ enzymatic activity with U73122, which is downstream of Itk, also reduced Itk binding to $\mathrm{PI}(3,4,5) \mathrm{P}_{3}$ (Fig. 5C). Conversely, increasing cytosolic $\mathrm{Ca}^{2+}$ concentration by inhibiting the $\mathrm{ER} \mathrm{Ca}^{2+}$ pump with Thapsigargin promoted Itk-mediated PLC $\gamma 1$ phosphorylation. However, TCR-induced activation of the 
upstream kinase Zap70 was unaffected by increased cytosolic $\mathrm{Ca}^{2+}$ levels (Fig. 5D).

Together, these data indicate the presence of $\mathrm{Ca}^{2+}$-dependent positive feedback on Itk activity.

\section{Disruption of CaM binding abrogates Itk recruitment to the immune synapse and IL-17A} production

Because pharmacologic inhibition of $\mathrm{CaM}$ can disrupt many signaling processes, we generated loop-swap Itk (LS-Itk) with mutations in the PH domain that selectively disrupted binding to $\mathrm{CaM}$ but not binding to $\mathrm{PI}(3,4,5) \mathrm{P}_{3}$. We used the following criteria to select the residues to mutate. (i)NMR analysis identified the Itk PH domain $\beta$-strands 2,3 , and 4 , and the $\beta 3 / \beta 4$ and $\beta 5 / \beta 6$ loops as the principal regions involved in CaM binding (Fig. 3B and C). (ii) We focused on the $\beta 3 / \beta 4$ and $\beta 5 / \beta 6$ loops, because these disordered regions may adopt a helical structure when CaM binds $(24,25)$; CaM binding to its targets typically involves association with a-helical structures (26). (iii) The closely related Btk PH domain does not bind $\mathrm{CaM}$ (Fig. 1A) and the amino acid sequences of both the $\beta 3 / \beta 4$ and $\beta 5 / \beta 6$ loops of the Btk PH domain differ from the corresponding regions in Itk. (iv) We focused on the smaller $\beta 3 / \beta 4$ loop region, the site of the interaction with the CaM C-domain in the presence or absence of $\mathrm{Ca}^{2+}$ (Fig. 4C and D). Thus, we swapped the 5-amino acid $\beta 3 / \beta 4$ loop in Itk with the corresponding 7 amino acids in Btk to produce LS-Itk (Fig. 6A). When expressed in 293 epithelial cells, LS-Itk exhibited reduced co-precipitation with CaM than did wild-type Itk (Fig. 6B). However, the association of LS-Itk with PI3,4,5P $\mathrm{P}_{3}$-coated beads was indistinguishable from that of wild-type Itk, suggesting that mutation in the $\beta 3 / \beta 4$ loop does not alter the fold of the PH domain. In contrast to LS-Itk, numerous mutations within the $\beta$ strands of the Itk $\mathrm{PH}$ domain either did not disrupt $\mathrm{CaM}$ binding or disrupted both $\mathrm{CaM}$ and $\mathrm{PI}(3,4,5) \mathrm{P}_{3}$ binding (table $\mathrm{S} 1$, fig. S3).

To investigate the role of $\mathrm{CaM}$ in recruiting Itk to the membrane of $\mathrm{T}$ cells, we assessed localization of Itk to the immunological synapse where $\mathrm{PI}(3,4,5) \mathrm{P}_{3}$ generation occurs using Jurkat $\mathrm{T}$ cells, which respond to CD3 stimulation by activating Akt and Itk-dependent PLC $\gamma 1$ (fig. S4). Although a fusion between wild-type Itk and YFP (WT-Itk-YFP) efficiently localized to actin-rich synapses formed between Jurkat $\mathrm{T}$ cells and Daudi B cells, the LS-Itk-YFP did not (Fig. 6C and fig. S5), indicating that Itk recruitment to the synapse required the presence of the $\beta 3-\beta 4$ loop native to Itk, not that of Btk. This implies that $\mathrm{CaM}$ is important for Itk membrane recruitment and subsequent Itk activation. To assess $\mathrm{Ca}^{2+}$ signaling, we reconstituted primary Itk-deficient $\mathrm{CD}^{+}{ }^{+} \mathrm{T}$ cells with either WT-Itk or LS-Itk, stimulated the TCR, and monitored the amount of cytosolic $\mathrm{Ca}^{2+}$. As previously reported for Itk-deficient $\mathrm{T}$ cells $(11,12), \mathrm{Ca}^{2+}$ did not change in response to TCR stimulation, as detected by the ratiometric $\mathrm{Ca}^{2+}$ indicator dye Indo-1 (Fig. 6D). However, TCR stimulation produced increased cytosolic $\mathrm{Ca}^{2+}$ in Itk-deficient $\mathrm{T}$ cells retrovirally reconstituted with WT-Itk, but not in those reconstituted with LS-Itk (Fig. 6D). Together, these data support a model in which initial increases in $\mathrm{Ca}^{2+}$ promote $\mathrm{CaM}$-mediated enhancement of Itk membrane recruitment and activation to further amplify $\mathrm{Ca}^{2+}$ signaling.

We also evaluated the importance of CaM binding to Itk on $\mathrm{T}$ cell functions that depend on Itk and $\mathrm{Ca}^{2+}$ signaling. Itk is required for NFAT-dependent IL-17A production by $\mathrm{T}_{\mathrm{H}} 17$ 
cells (14), an inflammatory $\mathrm{T}$ cell subset the deregulation of which has been implicated in mediating autoimmune diseases (15). Compared to cells reconstituted with WT-Itk, retroviral reconstitution of primary Itk-deficient $\mathrm{CD} 4^{+} \mathrm{T}$ cells with $\mathrm{LS}$-Itk failed to rescue IL-17A production (Fig. 6E), suggesting that positive feedback of Itk activity through $\mathrm{Ca}^{2+} / \mathrm{CaM}$ influences the efficiency of pro-inflammatory $\mathrm{T}$ cell responses.

\section{CaM is a putative protein ligand for multiple $\mathrm{PH}$ domains}

NMR analysis revealed that the $\beta 3 / \beta 4$ and $\beta 5 / \beta 6$ loops of the Itk PH domain interacted with $\mathrm{CaM}$. Given the general conservation of $\mathrm{PH}$ domain structure and loop positioning, we assessed the potential for $\mathrm{CaM}$ to bind other PH domains. We analyzed all annotated mouse PH domains in the UniProt database (27) for CaM binding potential using a prediction algorithm based on known CaM-binding proteins (28). Consistent with our experimental findings, the Itk $\mathrm{PH}$ domain was predicted to be a CaM-binding protein. In addition to Itk, we found that $49 \%$ of $236 \mathrm{PH}$ domains are predicted to bind to CaM, with $28 \%$ and $18 \%$ predicted to bind with intermediate and high affinities, respectively (Fig. 7A, table S3). To assess the accuracy of this prediction, we cloned ten $\mathrm{PH}$ domains from proteins of diverse function and tissue expression that were predicted to bind with low to high affinity and two PH domains with no predicted affinity (Fig. 7B). Coprecipitation assays with cell lysates containing PH domain-YFP fusion proteins showed that six of the predicted PH domains bound $\mathrm{CaM}$ in a $\mathrm{Ca}^{2+}$-dependent manner and that of the four predicted CaM-binding $\mathrm{PH}$ domains and both PH that were not predicted to bind CaM did not associate (Fig. 7B). Although further characterization of $\mathrm{CaM}$ binding to individual $\mathrm{PH}$ domains is required to substantiate these predictions, the data indicate that many PH domains may be regulated by $\mathrm{Ca}^{2+} / \mathrm{CaM}$, greatly expanding the number of potential effector proteins downstream of the second messenger $\mathrm{Ca}^{2+}$ and its binding partner $\mathrm{CaM}$

\section{Discussion}

$\mathrm{Ca}^{2+}$ is an important second messenger that regulates multiple cellular behaviors, including migration, differentiation, and death, and cellular processes, such as vesicular trafficking and enzyme activation. Precise control of the kinetics and magnitude of intracellular $\mathrm{Ca}^{2+}$ concentrations helps to activate the appropriate $\mathrm{Ca}^{2+}$-dependent response. In $\mathrm{T}$ cells, the TCR activates the Tec kinase Itk to induce $\mathrm{Ca}^{2+}$ signaling following recruitment of Itk to the membrane by $\mathrm{PI}(3,4,5) \mathrm{P}_{3}$. Here, we identified a positive feedback mechanism by which $\mathrm{Ca}^{2+} / \mathrm{CaM}$ cooperates with $\mathrm{PI}(3,4,5) \mathrm{P}_{3}$ for binding to the Itk $\mathrm{PH}$ domain and potentiates further Itk recruitment and activation. We mapped key interacting residues in both $\mathrm{CaM}$ and Itk and demonstrated that in the Itk PH domain the CaM-binding $\beta 3 / \beta 4$ loop that adjoins the $\mathrm{PI}(3,4,5) \mathrm{P}_{3}$ binding pocket is required for Itk-dependent amplification of production of the proinflammatory cytokine IL-17A. Lastly, we propose that $\mathrm{Ca}^{2+} / \mathrm{CaM}$ regulation may extend to other PH domains.

Distinct intracellular $\mathrm{Ca}^{2+}$ patterns contribute to different $\mathrm{T}$ cell differentiation programs. During $\mathrm{T}$ cell development, thymocytes with appropriate TCR affinities are positively selected to mature into $\mathrm{CD}^{+}$helper or $\mathrm{CD}^{+}$cytotoxic $\mathrm{T}$ cells, while cells with potentially autoreactive TCRs die by negative selection. $\mathrm{Ca}^{2+}$ patterns differ between thymocytes 
receiving maturation versus death signals. Sustained intermediate $\mathrm{Ca}^{2+}$ concentrations are induced during positive selection and high but transient $\mathrm{Ca}^{2+}$ concentrations are induced during negative selection of $\mathrm{CD}^{+}$cells (29). Peripheral $\mathrm{CD} 4^{+} \mathrm{T}$ cells also exhibit different patterns of $\mathrm{Ca}^{2+}$ signaling that are likely required for their differentiation and effector function. Although $\mathrm{T}_{\mathrm{H}} 1, \mathrm{~T}_{\mathrm{H}} 2$, and $\mathrm{T}_{\mathrm{H}} 17$ cells all respond to TCR stimulation by inducing a rapid spike in intracellular $\mathrm{Ca}^{2+}$ concentration, $\mathrm{T}_{\mathrm{H}} 1$ and to a lesser extent $\mathrm{T}_{\mathrm{H}} 17$ cells show sustained oscillatory $\mathrm{Ca}^{2+}$ signals (30). In contrast, $\mathrm{Ca}^{2+}$ concentrations in $\mathrm{T}_{\mathrm{H}} 2$ cells rapidly decrease following stimulation. Decreasing $\mathrm{Ca}^{2+}$ patterns translate into decreased amounts of nuclear NFAT (30). These studies emphasize the importance of tuning Itk-dependent $\mathrm{Ca}^{2+}$ signals to the appropriate degree to induce protective $\mathrm{T}$ cell responses. Interestingly, a report has identified a role for Itk in controlling the tissue infiltration of autoreactive $\mathrm{T}$ cells (31). Thus, targeting the $\mathrm{Ca}^{2+} / \mathrm{CaM}$ feedback loop that controls Itk activity identified here may present a new strategy for preventing tissue infiltration of autoimmune $\mathrm{T}$ cells, as well as therapeutic treatment of autoimmunity by limiting Itk-dependent IL-17A production.

Our data also support the changing perception of PH domains as multifunctional regulatory domains rather than simply membrane targeting domains (4). Indeed, less than a quarter of all mammalian PH domains bind lipids, and of those that do, less than $10 \%$ bind phosphoinositides with high specificity and affinity (1). Several PH domains bind directly to small guanosine triphosphatases (GTPases), including Cdc42, Rho, and Arf1 (ADPribosylation factor 1), through residues within the intervening $\beta$ loops of the $\mathrm{PH}$ domain (32-35). Here, the we found that the $\beta 3 / \beta 4$ - and $\beta 5 / \beta 6$-intervening loops of the Itk PH domain interact with $\mathrm{CaM}$ and are required for enhanced Itk association with $\mathrm{PI}(3,4,5) \mathrm{P}_{3}$. $\mathrm{CaM}$ also bind the Akt PH domain (36). Analysis of overlapping peptide fragments from the Akt PH domain localized CaM binding to a region within the $\beta$ barrel, representing an unconventional interaction. Interestingly, CaM functionally prevents the $\mathrm{PH}$ domain of Akt from binding $\mathrm{PI}(3,4,5) \mathrm{P}_{3}$, suggesting that $\mathrm{CaM}$ inhibits Akt activity (36). However, a separate study supports a positive role for $\mathrm{CaM}$ on Akt because $\mathrm{CaM}$ inhibitors reduce Aktdependent cell growth of breast tumor cell lines (37). Further structural and biochemical analyses as provided here for Itk will be required to determine the effect of CaM on Akt activation.

The finding that $\mathrm{CaM}$ interacts with the Itk $\mathrm{PH}$ domain and $\mathrm{PH}$ domains from a subset of other proteins suggests that these $\mathrm{PH}$ domain-containing proteins are putative effectors of $\mathrm{Ca}^{2+}$ signaling. CaM may allosterically regulate protein activity directly, as occurs with conventional CaM-binding effectors, or indirectly by integrating $\mathrm{Ca}^{2+}$ signals with those provided by GTPases or membrane phospholipids. For PH domains without lipid-binding potential or with uncharacterized function, lipid-binding potential should be (re-)evaluated in the presence of $\mathrm{Ca}^{2+} / \mathrm{CaM}$ in addition to assessing lipid-independent activities.

The precise mechanism by which the Itk $\mathrm{PH}$ domain, $\mathrm{Ca}^{2+} / \mathrm{CaM}$, and $\mathrm{PI}(3,4,5) \mathrm{P}_{3}$ work together to control and fine tune signals emanating from the TCR has yet to be firmly established. Several possibilities are emerging. Like the PH domains of certain guanine exchange factors (GEFs) for Rho (RhoGEFs) and the PH domain of Akt (38-41), the Itk PH domain may serve an autoinhibitory role. For Itk, association with $\mathrm{Ca}^{2+} / \mathrm{CaM}$ may prevent formation of an autoinhibitory structure, resulting in release of the Itk catalytic machinery 
and exposure of the lipid-binding pocket on the Itk PH domain for membrane anchoring. However, the closely related kinase Btk, which is present in B cells, mast cells, and myeloid cells, does not appear to be co-regulated by $\mathrm{CaM}$, suggesting that if $\mathrm{Ca}^{2+}$ responses in these cell types are amplified by positive feedback that it is not through the same mechanism we found for Itk in $\mathrm{T}$ cells.

Our NMR data and in vitro binding assays suggest a model for how CaM engages the Itk PH domain and how $\mathrm{PI}(3,4,5) \mathrm{P}_{3}$ (and not $\mathrm{IP}_{4}$ ) might cooperatively enhance the interaction between $\mathrm{CaM}$ and Itk. The emerging picture has parallels with the binding of $\mathrm{CaM}$ to the NMDA receptor NR1C0 site (42) and to melittin (43). In these complexes, the C-domain of apo-CaM binds the target with moderate affinity, and the $\mathrm{N}$-domain does not interact measurably. A rise in $\mathrm{Ca}^{2+}$, producing $\mathrm{Ca}^{2+} / \mathrm{CaM}$ causes both the $\mathrm{C}$-domaind and $\mathrm{N}$-domain to bind the target tightly. The apparent noncontiguous nature of the Itk PH domain as a $\mathrm{CaM}$ target is reminiscent of several other CaM-controlled systems; the ryanodine receptor, a protein that binds each domain of $\mathrm{CaM}$ through noncontiguous sites (44), the water-channel protein aquaporin- 0 engages $\mathrm{CaM}$ through two disparate regions (45), and voltage-gated sodium channels wherein $\mathrm{CaM}$ is thought to bridge a $\mathrm{C}$-terminal motif and a linker region that is distant in primary sequence (46). The noncontiguous Itk PH domain residues targeted by $\mathrm{Ca}^{2+} / \mathrm{CaM}$, in particular the $\beta 3 / \beta 4$ and $\beta 5 / \beta 6$ loops (Fig. $3 \mathrm{~B}$ and $\mathrm{C}$ ), may mediate binding to full-length $\mathrm{CaM}$ in a manner that requires $\mathrm{CaM}$ to maintain a semi-extended conformation rather than the collapsed conformation typical of many CaM-mediated interactions.

Precedence for $\mathrm{CaM}$ engaging its targets in an extended fashion include the synaptic vesicle priming protein, Munc13 (19), and the structure of CaM bound to the matrix (MA) domain of the HIV-1 Gag protein (47). In both cases, the distance between the centers of the two CaM-binding pockets (C-domain and N-domain) is approximately $36 \AA$, which corresponds to the $34 \AA$ distance from the $\beta 3 / \beta 4$ loop to the $\beta 5 / \beta 6$ loop in the Itk PH domain. The CaMMA complex structure also reveals that CaM binding modulates the fold of the MA domain (47), which we anticipate could also occur for the Itk PH domain leading to the induction of helix formation of the large $\beta 3 / \beta 4$ and $\beta 5 / \beta 6$ loops for optimal $\mathrm{CaM}$ binding.

Although our NMR titration data did not include $\mathrm{PI}(3,4,5) \mathrm{P}_{3}$, the Itk PH domain ligand, binding data suggested a role for $\mathrm{PI}(3,4,5) \mathrm{P}_{3}$ in stabilizing the CaM-PH domain interaction (Fig. 1D). The emerging model of an extended CaM protein binding the $\beta 3 / \beta 4$ and $\beta 5 / \beta 6$ loops of Itk PH does not appear mutually exclusive with $\mathrm{PI}(3,4,5) \mathrm{P}_{3}$ binding to the same $\mathrm{PH}$ domain (Fig. 3C). Interactions between $\mathrm{CaM}$ and the membrane, CaM-mediated conformational changes in the Itk PH domain that enhance lipid binding, or even structural changes in the membrane itself to fully accommodate a CaM-Itk-PI $(3,4,5) \mathrm{P}_{3}$ complex are all possibilities. Indeed, CaM interactions with myristoylated proteins have been described (4851), providing evidence for direct interaction between $\mathrm{CaM}$ and hydrophobic lipid-like structures.

Previous findings have suggested that soluble $\mathrm{IP}_{4}$ enhances Itk binding to $\mathrm{PI}(3,4,5) \mathrm{P}_{3}(21)$. In that case, Itk dimerization and allosteric communication across the protein-protein interface was invoked to explain how $\mathrm{IP}_{4}$ both enhances $\mathrm{PI}(3 ., 4,5) \mathrm{P}_{3}$ binding to the $\mathrm{PH}$ domain of Itk and binds to the same location as $\mathrm{PI}(3,4,5) \mathrm{P}_{3}$ on the $\mathrm{PH}$ domain. The extent to which Itk dimerization or oligomerization plays a role in the ability of $\mathrm{CaM}$ to enhance the 
association of Itk with $\mathrm{PI}(3,4,5) \mathrm{P}_{3}$ deserves further attention. However, we did not find an effect of $\mathrm{IP}_{4}$ on the CaM-Itk interaction. The previous findings were based in part on in-vitro binding experiments conducted in the absence of $\mathrm{Ca}^{2+}(21)$, precluding $\mathrm{Ca}^{2+} / \mathrm{CaM}$ interactions with Itk. Moreover, the physiological relevance of $\mathrm{IP}_{4}$ on Itk activation has only been explored in developing $\mathrm{T}$ cells in the thymus; $\mathrm{IP}_{4}$-deficient mice have a defect in $\mathrm{T}$ cell development $(21,52,53)$. The contribution of $\mathrm{IP}_{4}$ and its effect on $\mathrm{Ca}^{2+} / \mathrm{CaM}$ and $\mathrm{PI}(3,4,5) \mathrm{P}_{3}$ binding to Itk, and Itk-dependent $\mathrm{T}$ cell functions, such as $\mathrm{T}_{\mathrm{H}} 2$ and $\mathrm{T}_{\mathrm{H}} 17$ responses, remain unexplored in peripheral $\mathrm{T}$ cells. The possibility that $\mathrm{IP}_{4}$ and $\mathrm{CaM}$ independently promote Itk activity in a cell-stage or cell-type specific manner requires future assessment.

As further experiments clarify the mechanistic details for $\mathrm{Ca}^{2+} / \mathrm{CaM}$-regulation of Itkmediated signaling, we will gain a clearer understanding of how Itk activity is fine tuned to promote distinct $\mathrm{T}$ cell functions. The apparent complexity in Itk regulation is likely a reflection of how important controlling the magnitude and kinetics of $\mathrm{Ca}^{2+}$ responses is for balancing $\mathrm{T}$ cell responses to prevent immunodeficiency and autoimmunity, pathologies that may occur as a result of too little or too much TCR and Itk signaling.

\section{Materials and Methods}

\section{Mice, cell lines, plasmids}

All mice were housed under specific-pathogen-free conditions in the Washington University School of Medicine animal facilities in accordance with institutional guidelines. Lymphoid

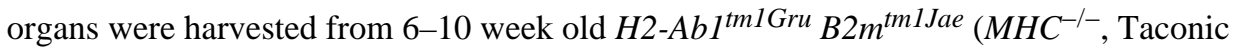
Farms, Model 4080) or $I t k^{-/-}$mice on the C57BL/6 background.

Wild-type and LS-mutant Itk were cloned into the pFLRu-YFP vector and were used to generate Jurkat stable cell lines as previously described (54). The human B cell line Daudi was stably transfected with pFLRu-Turquoise. Wild-type and LS-Itk were also cloned into a MSCV-based retrovirus (pCMV2.1) expressing GFP bicistronically as previously described (21) and used to transduce murine $\mathrm{CD} 4^{+} \mathrm{T}$ cells.

\section{Cloning and analysis of mouse $\mathrm{PH}$ domains}

RNA was prepared from various mouse tissues from C57BL/6 mice with TRIzol (Invitrogen). cDNA was synthesized with Supercript III reverse transcriptase (Invitrogen). Sequences for PH domains were cloned into pcDNA3.1 and tagged with YFP by introducing a BamHI (GGATCC) site within the reverse primer. A flexible linker (Gly-Gly-Gly-GlySer-Gly-Gly-Gly-Gly-Ser), which lacks a CaM-binding site, was introduced by PCR between the PH domain and YFP. The Cdc42bpa-PH domain, which contains an internal BamHI site, was cloned using a BgIII (AGATCT) site with a flexible linker (Gly-Gly-GlyArg-Ser-Gly-Gly-Gly-Gly-Ser). The Itk PH domain was cloned as a structural unit with the Tec homology domain. The boundaries for PH domains of unknown function were defined by combining the Uniprot annotations with domain predictions generated by Protein Homology/analogY Recognition Engine (Phyre) (55). Cloned PH domains preserved the Cterminal a helix without extraneous sequence extensions. LS-Itk was generated by bridge 
PCR mutation. Primers used for generating LS-Itk and Itk PH domain-YFP fusions are listed in table $\mathrm{S} 2$.

PH domain-YFP fusion proteins were expressed in 293 epithelial cells, and cell lysates were incubated with Apo-CaM- (with $1 \mathrm{mM}$ EGTA) or $\mathrm{Ca}^{2+} / \mathrm{CaM}$ - (with $100 \mathrm{nM} \mathrm{CaCl}_{2}$ ) coated beads (Sigma) for 1.5 hours at $4{ }^{\circ} \mathrm{C}$. Beads were washed 3-5 times with 1x lysis buffer $(1 \%$ Triton X-100, $60 \mathrm{mM}$ octylglucoside, $150 \mathrm{mM} \mathrm{NaCl}, 25 \mathrm{mM}$ Tris $\mathrm{pH}$ 7.5) containing protease (Mini Complete, EDTA-free Protease Inhibitor Cocktail, Roche) and phosphatase inhibitors (PhosSTOP, phosphatase inhibitor cocktail, Roche) and then denatured in 1x NuPAGE sample buffer (Life Technologies) at $99^{\circ} \mathrm{C}$ for 10 minutes prior to SDS-PAGE. Nitrocellulose membranes were probed overnight at $4^{\circ} \mathrm{C}$ with primary antibodies and 30-45 min. with secondary antibodies anti-rabbit or anti-mouse conjugated to horseradish peroxidase. PH domain-YFP fusion proteins were detected by Western blot using GFPspecific antibody (JL-8, cross-reactive with YFP, Clontech).

\section{Protein expression and purification for NMR studies}

Recombinant Itk PH domain used in this study contains the double mutation, C96E/T110I, that has been previously reported to facilitate production of soluble $\mathrm{PH}$ domain that retains $\mathrm{PI}(3,4,5) \mathrm{P}_{3}$ binding (18).

Itk PH domain C96E/T110I (amino acids 1-154, mus. musculus) was expressed and purified as previously described (18). Briefly, a modified pET20b vector was used to express Itk PH domain with an N-terminal His6-GB1 tag in (DE3)BL21 cells. Protein was purified using Ni-NTA chromatography, followed by Factor Xa cleavage of the His6-GB1 tag and sizeexclusion chromatography. The following rat Calmodulin constructs were expressed and purified as described previously (56): CaM-FL (1-148), CaM-C (76-148), CaM-N75 (175), CaM-N80 (1-80). For NMR titrations, proteins were dialyzed into $50 \mathrm{mM}$ HEPES pH 7.4, $150 \mathrm{mM} \mathrm{NaCl}, 2 \mathrm{mM}$ DTT, $0.02 \% \mathrm{NaN}_{3}$ (and $1 \mathrm{mM} \mathrm{CaCl}_{2}$ for $\mathrm{Ca}^{2+} / \mathrm{CaM}$ experiments). For apo-CaM titrations, $\mathrm{CaM}$ was treated with EGTA or EDTA and then dialyzed into calcium-free NMR buffer. The Itk PH domain has an extended region at its Cterminus that binds a $\mathrm{Zn}^{2+}$ ion that is likely necessary for the proper fold of this domain; hence, the dialysis was necessary to remove EDTA or EGTA prior to performing the experiments. For $\mathrm{Ca}^{2+} / \mathrm{CaM}$ experiments, a five-fold excess of $\mathrm{CaCl}_{2}$ was added to the purified $\mathrm{CaM}$, which was then dialyzed into $1 \mathrm{mM} \mathrm{CaCl}_{2} \mathrm{NMR}$ buffer.

\section{NMR Spectroscopy and ${ }^{1} \mathrm{H}^{15} \mathrm{~N}$ Backbone chemical shift assignments of ItkPH}

All NMR spectra were collected on a Bruker AVII 700 spectrometer with a $5 \mathrm{~mm} \mathrm{HCN} \mathrm{z-}$ gradient cryoprobe operating at a ${ }^{1} \mathrm{H}$ frequency $700.13 \mathrm{MHz}$, with a sample temperature of 298K. We assigned $75 \%$ of the backbone ${ }^{1} \mathrm{H} /{ }^{15} \mathrm{~N}$ chemical shifts using the Sparky (57) and MARS (58) software programs, utilizing the following pairs of triple-resonance experiments: $\mathrm{HNCA}$ and $\mathrm{HN}(\mathrm{CO}) \mathrm{CA}, \mathrm{HNCO}$ and $\mathrm{HN}(\mathrm{CA}) \mathrm{CO}$, and $\mathrm{CBCA}(\mathrm{CO}) \mathrm{NH}$ and CBCANH. Spectra are referenced to DSS, directly in the ${ }^{1} \mathrm{H}$ dimension and indirectly for the ${ }^{13} \mathrm{C}$ and ${ }^{15} \mathrm{~N}$ dimensions, according to standard procedures. NMRPipe (59) and NMRViewJ (60) were also used for data processing, visualization, and analysis. ${ }^{1} \mathrm{H}_{-}{ }^{15} \mathrm{~N}$ 
backbone assignments for CaM were obtained from the BMRB (61) (entry 6541 for ${ }^{15} \mathrm{~N}$ $\left.\mathrm{Ca}^{2+} / \mathrm{CaM}\right)$.

\section{NMR titrations}

NMR titrations were carried out as described previously (62). For each titration, unlabeled ligand (either Itk $\mathrm{PH}$ or $\mathrm{CaM}$ ) was added to ${ }^{15} \mathrm{~N}$-labeled protein and ${ }^{1} \mathrm{H}^{-15} \mathrm{~N}$ HSQC spectra were acquired for the indicated molar ratios. The concentration of ${ }^{15} \mathrm{~N}-\mathrm{Ca}^{2+} / \mathrm{CaM}$ was diluted from $150 \mu \mathrm{M}$ to $123 \mu \mathrm{M}$ over the course of the titration. For ${ }^{15} \mathrm{~N}$-Itk PH, the starting concentration of $300 \mu \mathrm{M}$ was diluted to $248 \mu \mathrm{M}$ by the final point of the titration.

\section{Structural model of the Itk PH domain}

The structural model of Itk PH domain used to interpret the NMR data was constructed with I-TASSER (63) and MODELLER (64), using the available Btk PH domain structures (PDB entries $1 \mathrm{BTK}$ and $1 \mathrm{~B} 55)$ as templates.

\section{Cell stimulations}

$M H C^{-/-}$thymocytes were rested at $37^{\circ} \mathrm{C}$ for $20-30$ minutes prior to stimulation. Thymocytes ( $2 \times 10^{7} /$ sample) were stained in phosphate-buffered saline (PBS) with biotinconjugated antibodies against CD3 and antibodies against CD4 for 15 minutes at $4{ }^{\circ} \mathrm{C}$. Following two washes in PBS, cells were stimulated with $1 \mu \mathrm{g} / \mathrm{ml}$ streptavidin in prewarmed PBS at $37^{\circ} \mathrm{C}$. Where indicated, thymocytes were pretreated with vehicle control, 30 $\mu \mathrm{M}$ of W-7 [N-(6-Aminohexyl)-5-chloro-1-naphthalenesulfonamide hydrochloride, Sigma A3281, MLCK $\left.\left(\mathrm{IC}_{50}=51 \mu \mathrm{M}\right)\right]$ or W-12 [N-(4-Aminobutyl)-2-naphthalenesulfonamide hydrochloride, Sigma A3168, $\left.\left.\operatorname{MLCK}\left(\mathrm{IC}_{50}=300 \mu \mathrm{M}\right)\right)\right] 10 \mu \mathrm{M}$ of BAPTA-AM (Sigma) with $5 \mathrm{mM}$ EGTA, or $5 \mu \mathrm{M}$ of U73122 (Cayman Chemical Company) prior to stimulation.

Jurkat $\mathrm{T}$ cells were rested in RPMI-1640 with $1 \%$ fetal bovine serum (FBS) overnight and then on ice for $1 \mathrm{hr}$. Cells $\left(10^{6}\right)$ in PBS were rested on ice for $30 \mathrm{~min}$ and then stimulated with $0.5 \mu \mathrm{g} / \mathrm{ml}$ antibody against CD3 (OKT3, eBioscience) in pre-warmed PBS at $37^{\circ} \mathrm{C}$.

Cells were lysed directly with 4x lysis buffer (4\% Triton X-100, $240 \mathrm{mM}$ octylglucoside, $600 \mathrm{mM} \mathrm{NaCl}, 100 \mathrm{mM}$ Tris pH 7.5, 4 mM EDTA) containing protease (Mini Complete, EDTA-free Protease Inhibitor Cocktail, Roche) and phosphatase inhibitors (PhosSTOP, phosphatase inhibitor cocktail, Roche). Lysates were cleared of cellular debris by centrifugation at $13,200 \mathrm{x}$ g for 15 minutes at $4^{\circ} \mathrm{C}$.

\section{Precipitation and immunoblot analyses}

Cell lysates or purified Itk PH domain were incubated with beads coated with $\mathrm{PI}(3,4,5) \mathrm{P}_{3}$ (Echelon Biosciences), Apo-CaM (with $1 \mathrm{mM}$ EGTA) or $\mathrm{Ca}^{2+} / \mathrm{CaM}$ (with $100 \mathrm{nM} \mathrm{CaCl} 2$ ) $\mathrm{CaM}$ (Sigma) for 1.5 hours at $4^{\circ} \mathrm{C} . \mathrm{PI}(3,4,5) \mathrm{P}_{3}, \mathrm{IP}_{4}$, or $\mathrm{PI}(4,5) \mathrm{P}_{2}$ were added to the precipitation system to study their effects on CaM binding to Itk. Beads were washed 3-5 times with $1 \mathrm{x}$ lysis buffer and then denatured in $1 \mathrm{x}$ sample buffer at $99^{\circ} \mathrm{C}$ for 10 minutes prior to SDS-PAGE. Nitrocellulose membranes were probed overnight at $4{ }^{\circ} \mathrm{C}$ with primary antibodies and 30-45 min. with secondary antibodies anti-rabbit or anti-mouse conjugated to horseradish peroxidase. Protein abundance was detected by chemiluminescence. Calmodulin 
(EP799Y)-specific antibody was from Abcam. Calcineurin-, Btk-, phosphorylated PLC $\gamma 1$ $\left(\right.$ Try $\left.^{783}\right)$-, phosphorylated Src $\left(\mathrm{Tyr}^{416}\right)$ - and phosphorylated ZAP-70 $\left(\mathrm{Tyr}^{319}\right)$-specific antibodies were from Cell Signaling Technologies. Itk-specific antibody was from BD Bioscience. GFP (JL-8)-specific antibody was from Clontech, and the GAPDH-HRP antibody was from Sigma.

\section{Calcium mobilization measurements}

Thymocytes were loaded with $1 \mu \mathrm{g} / \mathrm{ml}$ Fura-2-AM and $0.02 \%$ Pluronic (Invitrogen) in $\mathrm{Ca}^{2+}$ containing buffer $\left(1 \mathrm{mM} \mathrm{CaCl}_{2}, 135 \mathrm{mM} \mathrm{NaCl}, 5 \mathrm{mM} \mathrm{KCl}, 1 \mathrm{mM} \mathrm{MgCl} 2,5.6 \mathrm{mM}\right.$ glucose, $10 \mathrm{mM}$ HEPES pH 7.4, $0.1 \% \mathrm{BSA}$ ) at $37^{\circ} \mathrm{C}$ for $30 \mathrm{~min}$. After two washes, cells were resuspended in $\mathrm{Ca}^{2+}$-free buffer $(135 \mathrm{mM} \mathrm{NaCl}, 5 \mathrm{mM} \mathrm{KCl}, 1 \mathrm{mM} \mathrm{MgCl} 2,5.6 \mathrm{mM}$ glucose, $10 \mathrm{mM}$ HEPES $\mathrm{pH} 7.4,0.1 \% \mathrm{BSA}$ ) and transferred into a poly-L-lysine-treated 96 wellassay plate at $5 \times 10^{5}$ cells/well. Calcium response was measured on the FlexStation (Molecular Devices) at $37^{\circ} \mathrm{C}$ as previously described (65). $5 \mu \mathrm{g} / \mathrm{ml}$ of biotin-conjugated antibody against CD3 (2C11, Biolegend) and $1 \mu \mathrm{g} / \mathrm{ml}$ of biotin-conjugated antibody against CD4 (GK1.5, Biolegend) together with $15 \mu \mathrm{g} / \mathrm{ml}$ of streptavidin were used for TCR stimulation. $5 \mu \mathrm{g} / \mathrm{ml}$ of Ionomycin (Sigma) were used for inducing release of $\mathrm{Ca}^{2+}$ from ER in $\mathrm{Ca}^{2+}$-free extracellular buffer.

Wild-type and LS-mutant reconstituted $I t k^{-/-}$murine CD4 ${ }^{+} \mathrm{T}$ cells were rested without CD3 and CD28 stimulation for 48 hours before measuring calcium response. Cells were loaded with $1 \mu \mathrm{g} / \mathrm{ml}$ Indo-1-AM and $0.02 \%$ Pluronic (Invitrogen) in RPMI (10\% FBS) at $37^{\circ} \mathrm{C}$ for 30 min. Cells were washed twice and resuspended in RPMI (1\% FBS) and kept at room temperature. Cells were pre-warmed for $5 \mathrm{~min}$ at $37^{\circ} \mathrm{C}$ before experiments. Calcium response was measured on an LSRII flow cytometer (BD) by adding $10 \mu \mathrm{g} / \mathrm{ml}$ antibody against CD3 and $2.5 \mu \mathrm{g} / \mathrm{ml}$ antibody against CD4 followed by crosslinking with $25 \mu \mathrm{g} / \mathrm{ml}$ streptavidin. Calcium responses were recorded for $4 \mathrm{~min}$ after addition of streptavidin. The ratio of Indo-1 Violet to Indo-1 Blue was plotted over time for $\mathrm{GFP}^{+}$(reconstituted) and $\mathrm{GFP}^{-}$(non-transduced) cells.

\section{Immune synapse analyses}

Jurkat cells expressing either wild-type- or LS-mutant Itk-YFP fusion proteins were transfected with pRuby-LifeAct. Jurkat-Daudi conjugates were made as previously described (66). For quantification, conjugates were chosen randomly and manually scored for colocalization of actin and Itk by a blinded individual.

\section{$\mathrm{T}_{\mathrm{H}} \mathbf{1 7}$ polarization and retroviral transduction}

Naïve CD4 ${ }^{+} \mathrm{CD} 62 \mathrm{~L}^{+} \mathrm{CD} 25^{-} \mathrm{CD} 44^{-/ \text {low }}$ cells were purified from $\mathrm{Itk}^{-/-}$mice as previously described (14). Cells were cultured in plates coated with antibodies against CD3 (2C11, 10 $\mu \mathrm{g} / \mathrm{ml}$ ) and $\mathrm{CD} 28\left(37.51,5 \mu \mathrm{g} / \mathrm{ml}\right.$ ) under $\mathrm{T}_{\mathrm{H}} 0$ condition (see below) for $48 \mathrm{hr}$ and then under $\mathrm{T}_{\mathrm{H}} 17$ conditions for an additional $48 \mathrm{hr}$. $\mathrm{T}_{\mathrm{H}} 17$ cells were stimulated with $50 \mathrm{ng} / \mathrm{ml}$ of Phorbol 12-myristate 13-acetate (PMA, Sigma) and $1 \mu \mathrm{g} / \mathrm{ml}$ of ionomycin (Sigma) in presence of Brefeldin A (Biolegend) for $4 \mathrm{hr}$. Cells were fixed and permeabilized with Cytofix/Cytoperm kit (BD Biosciences) and stained for surface CD4 and intracellular IL-17A and IFN- $\gamma$. $\mathrm{T}_{\mathrm{H}} 0$ condition: $10 \mu \mathrm{g} / \mathrm{ml}$ each of antibodies against IL-4 (11B11), IFN- $\gamma$ 
(H22), and IL-12 (17.8) (Biolegend) in IMDM supplemented with 10\% FBS (HyClone), 100 $\mathrm{U} / \mathrm{ml}$ penicillin, $100 \mu \mathrm{g} / \mathrm{ml}$ streptomycin, $2 \mathrm{mM} \mathrm{L}$-glutamine, and $55 \mu \mathrm{M}$ 2-mercaptoethanol (Invitrogen); $\mathrm{T}_{\mathrm{H}} 17$ condition: $\mathrm{T}_{\mathrm{H}} 0$ condition supplemented with $20 \mathrm{ng} / \mathrm{ml}$ of IL-6 (Peprotech), $5 \mathrm{ng} / \mathrm{ml}$ of TGF $\beta 1$ (R\&D), $10 \mathrm{ng} / \mathrm{ml}$ of IL-1 $\beta$ (Peprotech), and $10 \mathrm{ng} / \mathrm{ml}$ of IL-23 (R\&D).

Itk-encoding retroviruses were packaged by transfection of PlatE cells (67) with Fugene 6 (Roche). Retroviral supernatants were collected at $48 \mathrm{hrs}$ after transfection, filtered through $0.45 \mu \mathrm{M}$ filters, and used to spinoculate T cells on day 2 of culture at $2500 \mathrm{rpm}$ for $1.5 \mathrm{hr}$ at room temperature with $8 \mu \mathrm{g} / \mathrm{ml}$ of polybrene (Sigma).

\section{Supplementary Material}

Refer to Web version on PubMed Central for supplementary material.

\section{Acknowledgments}

We thank N. Mathis for technical assistance, Y. Feng for pFLRu and pRuby-LifeAct constructs, and M. Ikura for discussion on $\mathrm{CaM}$ binding prediction. This study was supported by the National Institutes of Health grants GM057001 (M.A.S), AI043957 (A.H.A.) and AI089805 (Y.H.H).

\section{References}

1. Lemmon MA. Pleckstrin homology (PH) domains and phosphoinositides. Biochem Soc Symp. 2007:81-93. [PubMed: 17233582]

2. Xu Q, Bateman A, Finn RD, Abdubek P, Astakhova T, Axelrod HL, Bakolitsa C, Carlton D, Chen C, Chiu HJ, Chiu M, Clayton T, Das D, Deller MC, Duan L, Ellrott K, Ernst D, Farr CL, Feuerhelm J, Grant JC, Grzechnik A, Han GW, Jaroszewski L, Jin KK, Klock HE, Knuth MW, Kozbial P, Krishna SS, Kumar A, Marciano D, McMullan D, Miller MD, Morse AT, Nigoghossian E, Nopakun A, Okach L, Puckett C, Reyes R, Rife CL, Sefcovic N, Tien HJ, Trame CB, van den Bedem H, Weekes D, Wooten T, Hodgson KO, Wooley J, Elsliger MA, Deacon AM, Godzik A, Lesley SA, Wilson IA. Bacterial pleckstrin homology domains: a prokaryotic origin for the PH domain. J Mol Biol. 2010; 396:31-46. [PubMed: 19913036]

3. Yu JW, Mendrola JM, Audhya A, Singh S, Keleti D, DeWald DB, Murray D, Emr SD, Lemmon MA. Genome-wide analysis of membrane targeting by S. cerevisiae pleckstrin homology domains. Mol Cell. 2004; 13:677-688. [PubMed: 15023338]

4. Moravcevic K, Oxley CL, Lemmon MA. Conditional peripheral membrane proteins: facing up to limited specificity. Structure. 2012; 20:15-27. [PubMed: 22193136]

5. Harlan JE, Hajduk PJ, Yoon HS, Fesik SW. Pleckstrin homology domains bind to phosphatidylinositol-4,5-bisphosphate. Nature. 1994; 371:168-170. [PubMed: 8072546]

6. Vanhaesebroeck B, Stephens L, Hawkins P. PI3K signalling: the path to discovery and understanding. Nat Rev Mol Cell Biol. 2012; 13:195-203. [PubMed: 22358332]

7. Rawlings DJ, Saffran DC, Tsukada S, Largaespada DA, Grimaldi JC, Cohen L, Mohr RN, Bazan JF, Howard M, Copeland NG, et al. Mutation of unique region of Bruton's tyrosine kinase in immunodeficient XID mice. Science. 1993; 261:358-361. [PubMed: 8332901]

8. Thomas JD, Sideras P, Smith CI, Vorechovsky I, Chapman V, Paul WE. Colocalization of X-linked agammaglobulinemia and X-linked immunodeficiency genes. Science. 1993; 261:355-358. [PubMed: 8332900]

9. Li T, Tsukada S, Satterthwaite A, Havlik MH, Park H, Takatsu K, Witte ON. Activation of Bruton's tyrosine kinase (BTK) by a point mutation in its pleckstrin homology (PH) domain. Immunity. 1995; 2:451-460. [PubMed: 7538439] 
10. Andreotti AH, Schwartzberg PL, Joseph RE, Berg LJ. T-cell signaling regulated by the Tec family kinase, Itk. Cold Spring Harb Perspect Biol. 2010; 2:a002287. [PubMed: 20519342]

11. Liu KQ, Bunnell SC, Gurniak CB, Berg LJ. T cell receptor-initiated calcium release is uncoupled from capacitative calcium entry in Itk-deficient T cells. J Exp Med. 1998; 187:1721-1727. [PubMed: 9584150]

12. Fowell DJ, Shinkai K, Liao XC, Beebe AM, Coffman RL, Littman DR, Locksley RM. Impaired NFATc translocation and failure of Th2 development in Itk-deficient CD4+ T cells. Immunity. 1999; 11:399-409. [PubMed: 10549622]

13. Schaeffer EM, Yap GS, Lewis CM, Czar MJ, McVicar DW, Cheever AW, Sher A, Schwartzberg PL. Mutation of Tec family kinases alters T helper cell differentiation. Nat Immunol. 2001; 2:1183-1188. [PubMed: 11702066]

14. Gomez-Rodriguez J, Sahu N, Handon R, Davidson TS, Anderson SM, Kirby MR, August A, Schwartzberg PL. Differential expression of interleukin-17A and $-17 \mathrm{~F}$ is coupled to T cell receptor signaling via inducible T cell kinase. Immunity. 2009; 31:587-597. [PubMed: 19818650]

15. Maddur MS, Miossec P, Kaveri SV, Bayry J. Th17 cells: biology, pathogenesis of autoimmune and inflammatory diseases, and therapeutic strategies. Am J Pathol. 2012; 181:8-18. [PubMed: 22640807]

16. Clapham DE. Calcium signaling. Cell. 2007; 131:1047-1058. [PubMed: 18083096]

17. Feske S. Calcium signalling in lymphocyte activation and disease. Nat Rev Immunol. 2007; 7:690702. [PubMed: 17703229]

18. Boyken SE, Fulton DB, Andreotti AH. Rescue of the aggregation prone Itk Pleckstrin Homology domain by two mutations derived from the related kinases, Btk and Tec. Protein Sci. 2012; 21:1288-1297. [PubMed: 22761113]

19. Rodriguez-Castaneda F, Maestre-Martinez M, Coudevylle N, Dimova K, Junge H, Lipstein N, Lee D, Becker S, Brose N, Jahn O, Carlomagno T, Griesinger C. Modular architecture of Munc13/ calmodulin complexes: dual regulation by $\mathrm{Ca} 2+$ and possible function in short-term synaptic plasticity. EMBO J. 2010; 29:680-691. [PubMed: 20010694]

20. Zhang M, Tanaka T, Ikura M. Calcium-induced conformational transition revealed by the solution structure of apo calmodulin. Nature structural biology. 1995; 2:758-767.

21. Huang YH, Grasis JA, Miller AT, Xu R, Soonthornvacharin S, Andreotti AH, Tsoukas CD, Cooke MP, Sauer K. Positive regulation of Itk PH domain function by soluble IP4. Science. 2007; 316:886-889. [PubMed: 17412921]

22. Singleton KL, Gosh M, Dandekar RD, Au-Yeung BB, Ksionda O, Tybulewicz VL, Altman A, Fowell DJ, Wulfing C. Itk controls the spatiotemporal organization of T cell activation. Sci Signal. 2011; 4:ra66. [PubMed: 21971040]

23. Osawa M, Swindells MB, Tanikawa J, Tanaka T, Mase T, Furuya T, Ikura M. Solution structure of calmodulin-W-7 complex: the basis of diversity in molecular recognition. J Mol Biol. 1998; 276:165-176. [PubMed: 9514729]

24. Radivojac P, Vucetic S, O'Connor TR, Uversky VN, Obradovic Z, Dunker AK. Calmodulin signaling: analysis and prediction of a disorder-dependent molecular recognition. Proteins. 2006; 63:398-410. [PubMed: 16493654]

25. Nagulapalli M, Parigi G, Yuan J, Gsponer J, Deraos G, Bamm VV, Harauz G, Matsoukas J, de Planque MR, Gerothanassis IP, Babu MM, Luchinat C, Tzakos AG. Recognition pliability is coupled to structural heterogeneity: a calmodulin intrinsically disordered binding region complex. Structure. 2012; 20:522-533. [PubMed: 22405011]

26. Crivici A, Ikura M. Molecular and structural basis of target recognition by calmodulin. Annual review of biophysics and biomolecular structure. 1995; 24:85-116.

27. Consortium U. Reorganizing the protein space at the Universal Protein Resource (UniProt). Nucleic Acids Res. 2012; 40:D71-75. [PubMed: 22102590]

28. Yap KL, Kim J, Truong K, Sherman M, Yuan T, Ikura M. Calmodulin target database. J Struct Funct Genomics. 2000; 1:8-14. [PubMed: 12836676]

29. Lo WL, Donermeyer DL, Allen PM. A voltage-gated sodium channel is essential for the positive selection of CD4(+) T cells. Nat Immunol. 2012; 13:880-887. [PubMed: 22842345] 
30. Weber KS, Miller MJ, Allen PM. Th17 cells exhibit a distinct calcium profile from Th1 and Th2 cells and have Th1-like motility and NF-AT nuclear localization. J Immunol. 2008; 180:14421450. [PubMed: 18209039]

31. Jain N, Miu B, Jiang JK, McKinstry KK, Prince A, Swain SL, Greiner DL, Thomas CJ, Sanderson MJ, Berg LJ, Kang J. CD28 and ITK signals regulate autoreactive T cell trafficking. Nature medicine. 2013

32. Chen Z, Medina F, Liu MY, Thomas C, Sprang SR, Sternweis PC. Activated RhoA binds to the pleckstrin homology (PH) domain of PDZ-RhoGEF, a potential site for autoregulation. J Biol Chem. 2010; 285:21070-21081. [PubMed: 20430886]

33. Chhatriwala MK, Betts L, Worthylake DK, Sondek J. The DH and PH domains of Trio coordinately engage Rho GTPases for their efficient activation. J Mol Biol. 2007; 368:1307-1320. [PubMed: 17391702]

34. Godi A, Di Campli A, Konstantakopoulos A, Di Tullio G, Alessi DR, Kular GS, Daniele T, Marra P, Lucocq JM, De Matteis MA. FAPPs control Golgi-to-cell-surface membrane traffic by binding to ARF and PtdIns(4)P. Nat Cell Biol. 2004; 6:393-404. [PubMed: 15107860]

35. Snyder JT, Worthylake DK, Rossman KL, Betts L, Pruitt WM, Siderovski DP, Der CJ, Sondek J. Structural basis for the selective activation of Rho GTPases by Dbl exchange factors. Nature structural biology. 2002; 9:468-475.

36. Dong B, Valencia CA, Liu R. Ca(2+)/calmodulin directly interacts with the pleckstrin homology domain of AKT1. J Biol Chem. 2007; 282:25131-25140. [PubMed: 17580302]

37. Coticchia CM, Revankar CM, Deb TB, Dickson RB, Johnson MD. Calmodulin modulates Akt activity in human breast cancer cell lines. Breast cancer research and treatment. 2009; 115:545560. [PubMed: 18587642]

38. Bi F, Debreceni B, Zhu K, Salani B, Eva A, Zheng Y. Autoinhibition mechanism of proto-Dbl. Mol Cell Biol. 2001; 21:1463-1474. [PubMed: 11238883]

39. Calleja V, Alcor D, Laguerre M, Park J, Vojnovic B, Hemmings BA, Downward J, Parker PJ, Larijani B. Intramolecular and intermolecular interactions of protein kinase B define its activation in vivo. PLoS biology. 2007; 5:e95. [PubMed: 17407381]

40. Calleja V, Laguerre M, Parker PJ, Larijani B. Role of a novel PH-kinase domain interface in $\mathrm{PKB} /$ Akt regulation: structural mechanism for allosteric inhibition. PLoS biology. 2009; 7:e17. [PubMed: 19166270]

41. Das B, Shu X, Day GJ, Han J, Krishna UM, Falck JR, Broek D. Control of intramolecular interactions between the pleckstrin homology and Dbl homology domains of Vav and Sos1 regulates Rac binding. J Biol Chem. 2000; 275:15074-15081. [PubMed: 10748082]

42. Akyol Z, Bartos JA, Merrill MA, Faga LA, Jaren OR, Shea MA, Hell JW. Apo-calmodulin binds with its C-terminal domain to the N-methyl-D-aspartate receptor NR1 C0 region. J Biol Chem. 2004; 279:2166-2175. [PubMed: 14530275]

43. Newman RA, Van Scyoc WS, Sorensen BR, Jaren OR, Shea MA. Interdomain cooperativity of calmodulin bound to melittin preferentially increases calcium affinity of sites I and II. Proteins. 2008; 71:1792-1812. [PubMed: 18175310]

44. Xiong LW, Newman RA, Rodney GG, Thomas O, Zhang JZ, Persechini A, Shea MA, Hamilton SL. Lobe-dependent regulation of ryanodine receptor type 1 by calmodulin. J Biol Chem. 2002; 277:40862-40870. [PubMed: 12185083]

45. Reichow SL, Clemens DM, Freites JA, Nemeth-Cahalan KL, Heyden M, Tobias DJ, Hall JE, Gonen T. Allosteric mechanism of water-channel gating by Ca2+-calmodulin. Nat Struct Mol Biol. 2013; 20:1085-1092. [PubMed: 23893133]

46. Sarhan MF, Tung CC, Van Petegem F, Ahern CA. Crystallographic basis for calcium regulation of sodium channels. Proc Natl Acad Sci U S A. 2012; 109:3558-3563. [PubMed: 22331908]

47. Vlach J, Samal AB, Saad JS. Solution structure of calmodulin bound to the binding domain of the HIV-1 matrix protein. J Biol Chem. 2014; 289:8697-8705. [PubMed: 24500712]

48. Hayashi N, Matsubara M, Jinbo Y, Titani K, Izumi Y, Matsushima N. Nef of HIV-1 interacts directly with calcium-bound calmodulin. Protein Sci. 2002; 11:529-537. [PubMed: 11847276] 
49. Matsubara M, Jing T, Kawamura K, Shimojo N, Titani K, Hashimoto K, Hayashi N. Myristoyl moiety of HIV Nef is involved in regulation of the interaction with calmodulin in vivo. Protein Sci. 2005; 14:494-503. [PubMed: 15632291]

50. Matsubara M, Nakatsu T, Kato H, Taniguchi H. Crystal structure of a myristoylated CAP-23/ NAP-22 N-terminal domain complexed with Ca2+/calmodulin. EMBO J. 2004; 23:712-718. [PubMed: 14765114]

51. Matsubara M, Titani K, Taniguchi H, Hayashi N. Direct involvement of protein myristoylation in myristoylated alanine-rich C kinase substrate (MARCKS)-calmodulin interaction. J Biol Chem. 2003; 278:48898-48902. [PubMed: 14506265]

52. Pouillon V, Hascakova-Bartova R, Pajak B, Adam E, Bex F, Dewaste V, Van Lint C, Leo O, Erneux C, Schurmans S. Inositol 1,3,4,5-tetrakisphosphate is essential for T lymphocyte development. Nat Immunol. 2003; 4:1136-1143. [PubMed: 14517551]

53. Wen BG, Pletcher MT, Warashina M, Choe SH, Ziaee N, Wiltshire T, Sauer K, Cooke MP. Inositol $(1,4,5)$ trisphosphate 3 kinase B controls positive selection of T cells and modulates Erk activity. Proc Natl Acad Sci U S A. 2004; 101:5604-5609. [PubMed: 15064401]

54. Feng Y, Nie L, Thakur MD, Su Q, Chi Z, Zhao Y, Longmore GD. A multifunctional lentiviralbased gene knockdown with concurrent rescue that controls for off-target effects of RNAi. Genomics Proteomics Bioinformatics. 2010; 8:238-245. [PubMed: 21382592]

55. Kelley LA, Sternberg MJ. Protein structure prediction on the Web: a case study using the Phyre server. Nat Protoc. 2009; 4:363-371. [PubMed: 19247286]

56. Sorensen BR, Faga LA, Hultman R, Shea MA. An interdomain linker increases the thermostability and decreases the calcium affinity of the calmodulin N-domain. Biochemistry. 2002; 41:15-20. [PubMed: 11771998]

57. Goddard, TD. University of California; San Francisco:

58. Jung YS, Zweckstetter M. Mars -- robust automatic backbone assignment of proteins. Journal of biomolecular NMR. 2004; 30:11-23. [PubMed: 15452431]

59. Delaglio F, Grzesiek S, Vuister GW, Zhu G, Pfeifer J, Bax A. NMRPipe: a multidimensional spectral processing system based on UNIX pipes. Journal of biomolecular NMR. 1995; 6:277293. [PubMed: 8520220]

60. Johnson BA. Using NMRView to visualize and analyze the NMR spectra of macromolecules. Methods Mol Biol. 2004; 278:313-352. [PubMed: 15318002]

61. Ulrich EL, Akutsu H, Doreleijers JF, Harano Y, Ioannidis YE, Lin J, Livny M, Mading S, Maziuk D, Miller Z, Nakatani E, Schulte CF, Tolmie DE, Kent Wenger R, Yao H, Markley JL. BioMagResBank. Nucleic Acids Res. 2008; 36:D402-408. [PubMed: 17984079]

62. Severin A, Joseph RE, Boyken S, Fulton DB, Andreotti AH. Proline isomerization preorganizes the Itk SH2 domain for binding to the Itk SH3 domain. J Mol Biol. 2009; 387:726-743. [PubMed: 19361414]

63. Roy A, Kucukural A, Zhang Y. I-TASSER: a unified platform for automated protein structure and function prediction. Nat Protoc. 2010; 5:725-738. [PubMed: 20360767]

64. Sali A, Blundell TL. Comparative protein modelling by satisfaction of spatial restraints. J Mol Biol. 1993; 234:779-815. [PubMed: 8254673]

65. Marshall IC, Boyfield I, McNulty S. Ratiometric $\mathrm{Ca}(2)(+)$ measurements using the FlexStation((R))Scanning Fluorometer. Methods Mol Biol. 2013; 937:95-101. [PubMed: 23007580]

66. Lin J, Weiss A. The tyrosine phosphatase CD148 is excluded from the immunologic synapse and down-regulates prolonged T cell signaling. J Cell Biol. 2003; 162:673-682. [PubMed: 12913111]

67. Morita S, Kojima T, Kitamura T. Plat-E: an efficient and stable system for transient packaging of retroviruses. Gene Ther. 2000; 7:1063-1066. [PubMed: 10871756] 
A

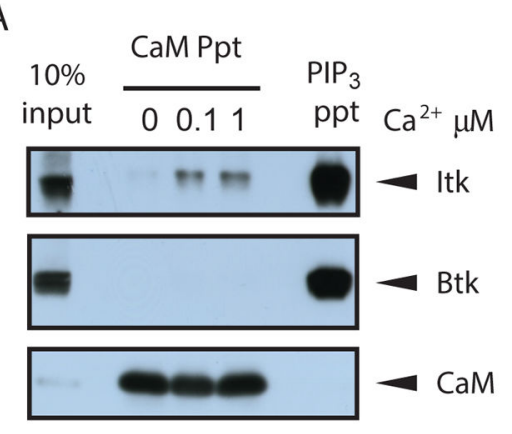

B

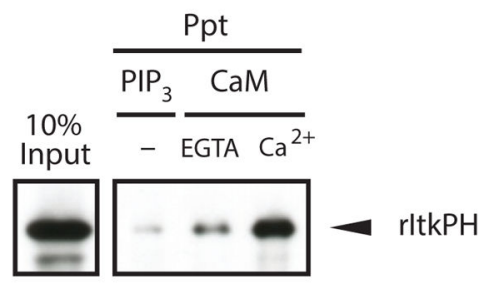

C
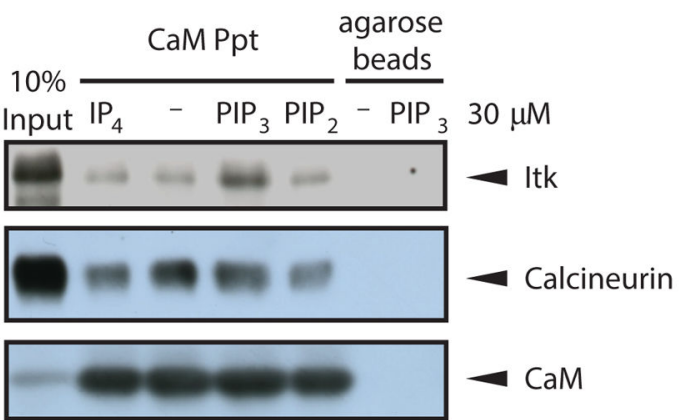

D

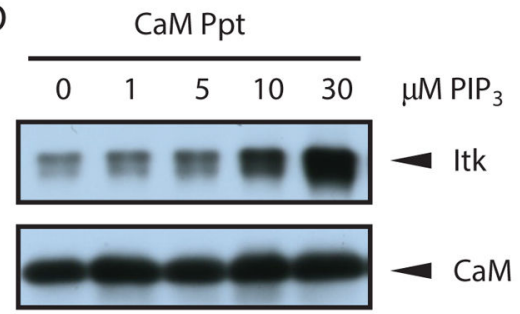

Fig 1. Itk association with $\mathrm{CaM}$ is $\mathrm{Ca}^{2+}$ dependent and enhanced by $\mathrm{PI}(3,4,5) \mathrm{P}_{3}$ binding (A) CaM coprecipitation of endogenous Itk or Btk from mouse splenocyte lysates was perfomed with the indicated concentrations of $\mathrm{Ca} 2+$ in the precipitation buffer. Affinity purification with $\mathrm{PI}(3,4,5) \mathrm{P}_{3}$-coated beads served as a positive control. (B) Direct comparison of recombinant Itk PH domain binding to $\mathrm{PI}(3,4,5) \mathrm{P}_{3}$, Apo-CaM (EGTA), and $\mathrm{Ca}^{2+} / \mathrm{CaM}\left(\mathrm{Ca}^{2+}\right)$. (C) Effect of $\mathrm{PIP}_{3}, \mathrm{IP}_{4}$ and $\mathrm{PIP}_{2}$ addition on the coprecipitation of Itk or calcineuron with $\mathrm{CaM}$ from primary $\mathrm{T}$ cell lysates. (D) Dose-dependent enhancement of Itk binding to $\mathrm{CaM}$ by addition of $\mathrm{PI}(3,4,5) \mathrm{P}_{3}$. All data are representative of 3 experiments. $\mathrm{PIP}_{2}, \mathrm{PI}(4,5) \mathrm{P}_{2} ; \mathrm{PIP}_{3}, \mathrm{PI}(3,4,5) \mathrm{P}_{3} ; \mathrm{IP}_{4}$, Ins $(1,3,4,5) \mathrm{P}_{4}$; ppt, precipitation; rItkPH, recombinant Itk $\mathrm{PH}$ domain 

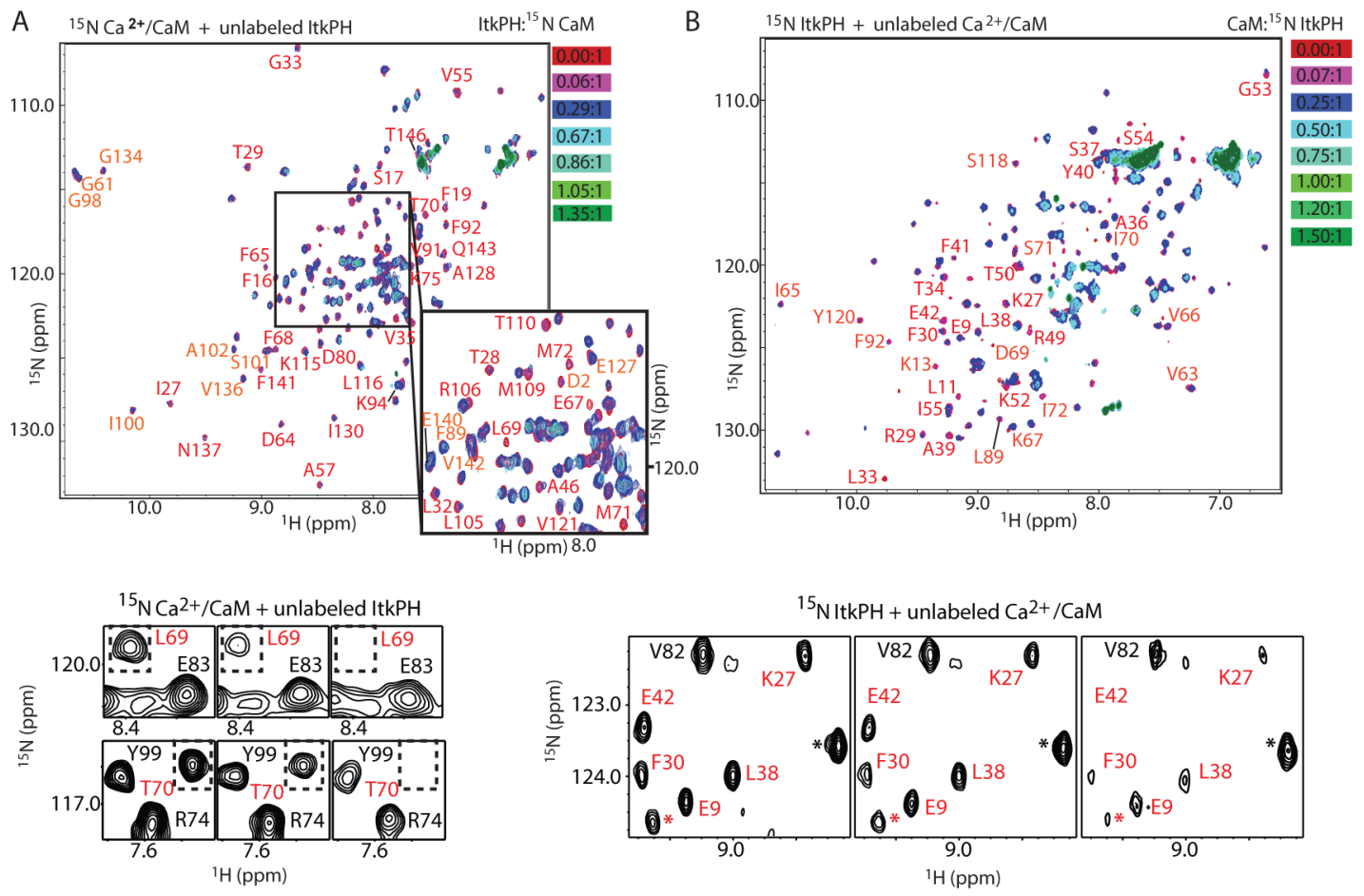

Fig 2. Structural characterization of the binding interface between the Itk PH domain and CaM (A) (top) Overlay of ${ }^{1} \mathrm{H}-{ }^{15} \mathrm{~N}-\mathrm{HSQC}$ spectra of $150 \mu \mathrm{M}{ }^{15} \mathrm{~N}-\mathrm{Ca}^{2+} / \mathrm{CaM}$ with unlabeled Itk $\mathrm{PH}$ domain titrated at indicated molar ratios (red to green); residues with the largest spectral changes upon binding are labeled. (bottom) Representative regions of the ${ }^{1} \mathrm{H}-{ }^{15} \mathrm{~N}-\mathrm{HSQC}$ spectra for the first three points in the titration showing line-broadening of the selected CaM resonances (labeled in red and boxed). Resonances that show only partial line broadening are labeled in black. (B) (top) Overlay of ${ }^{1} \mathrm{H}-1{ }^{15} \mathrm{~N}-\mathrm{HSQC}$ spectra of $300 \mu \mathrm{M}{ }^{15} \mathrm{~N}$-ItkPH with unlabeled $\mathrm{Ca}^{2+} / \mathrm{CaM}$ titrated at indicated molar ratios (red to green); residues showing significant spectral changes are labeled. (bottom) Representative regions of the ${ }^{1} \mathrm{H}-{ }^{15} \mathrm{~N}-$ HSQC spectra for the first three points in the titration showing line-broadening of the selected Itk PH domain resonances (labeled in red). Resonances that show modest line broadening (presumably due to increased molecular weight of the complex rather than direct interaction with $\mathrm{CaM}$ ) are labeled in black. Asterisk $(*)$ indicates resonances that could not be unequivocally assigned. 
A $\mathrm{Ca}^{2+/ \mathrm{CaM}}$

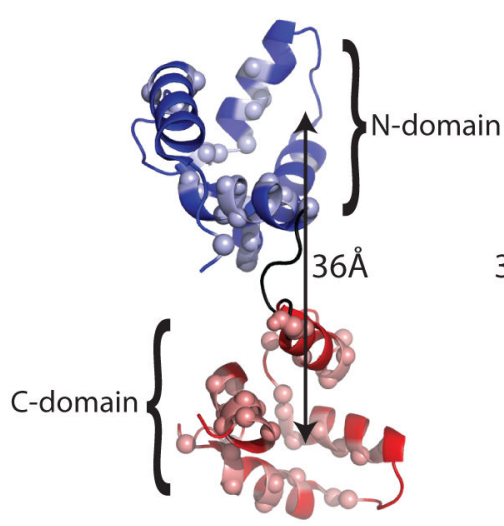

ItkPH (model)

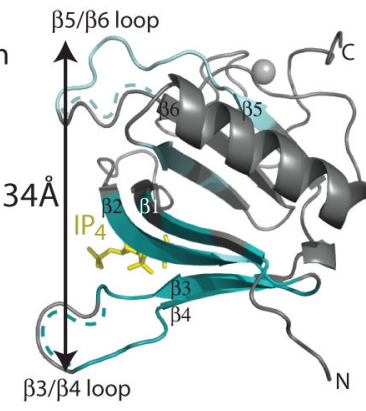

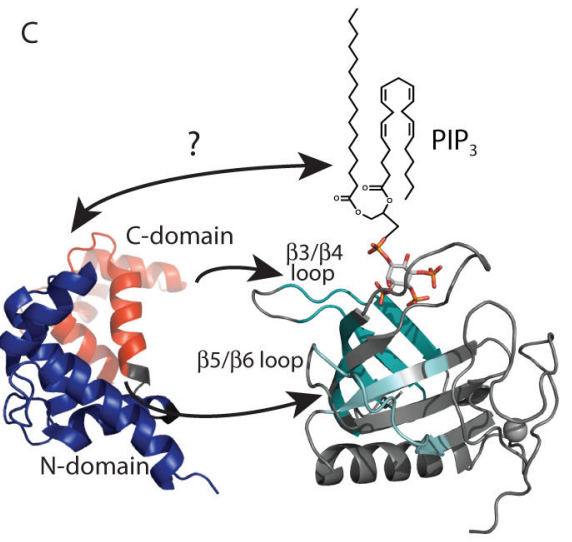

Fig 3. Structural models of the binding interface between the Itk PH domain and CaM (A) Spectral changes induced by addition of the Itk PH domain mapped onto the $\mathrm{Ca}^{2+} / \mathrm{CaM}$ structure (PDB entry 2KDU). Blue spheres indicate $\mathrm{N}$-domain residues perturbed on binding of the Itk PH domain to $\mathrm{Ca}^{2+} / \mathrm{CaM}$ and red spheres indicate $\mathrm{C}$-domain residues affected by binding. The doubled headed arrow indicates the $36 \AA$ distance between the two lobes in this extended structure of $\mathrm{Ca}^{2+} / \mathrm{CaM}$. (B) Spectral changes are induced by addition of $\mathrm{CaM}$ mapped onto a structural model of the Itk PH domain bound to $\mathrm{IP}_{4} \cdot \mathrm{IP}_{4}$ is in yellow, the gray ball is a bound zinc ion, and the regions of the PH domain for which the NMR resonances were affected upon addition of $\mathrm{Ca}^{2+} / \mathrm{CaM}$ are indicated in cyan. For both the $\beta 3 / \beta 4$ loop and the $\beta 5 / \beta 6$ loop the dotted lines indicate regions for which NMR assignments could not be completed. Because chemical shift mapping suggest that the $\beta 5$ strand and the $\beta 5 / \beta 6$ loop along with the $\beta 4$ strand and the $\beta 3 / \beta 4$ loop are the CaM target sites, the $34 \AA$ distance between the sites is indicated for comparison to the distance between the $\mathrm{N}$ - and $\mathrm{C}$-domains of CaM shown in panel (A). (C) Alternative view of the Itk $\mathrm{PH}$ domain with the $\mathrm{IP}_{4}$-binding site at the top and the lipid chain present in $\mathrm{PI}(3,4,5) \mathrm{P}_{3}$ added to indicate the possible location of the membrane relative to the CaM-binding site on the Itk PH domain. Another representative structure of $\mathrm{Ca}^{2+}-\mathrm{CaM}$ (PDB entry $2 \mathrm{MGU}$ ) is shown in an orientation that would allow the $\mathrm{N}$ - and $\mathrm{C}$-domains to contact the $\mathrm{PH}$ domain $\beta 5 / \beta 6$ and $\beta 3 / \beta 4$ loops, respectively. The arrow between $\mathrm{CaM}$ and $\mathrm{PI}(3,4,5) \mathrm{P}_{3}$ indicates the possibility for additional contacts that may contribute to the observed cooperativity. $\mathrm{PIP}_{3}, \mathrm{PI}(3,4,5) \mathrm{P}_{3}$ 
A

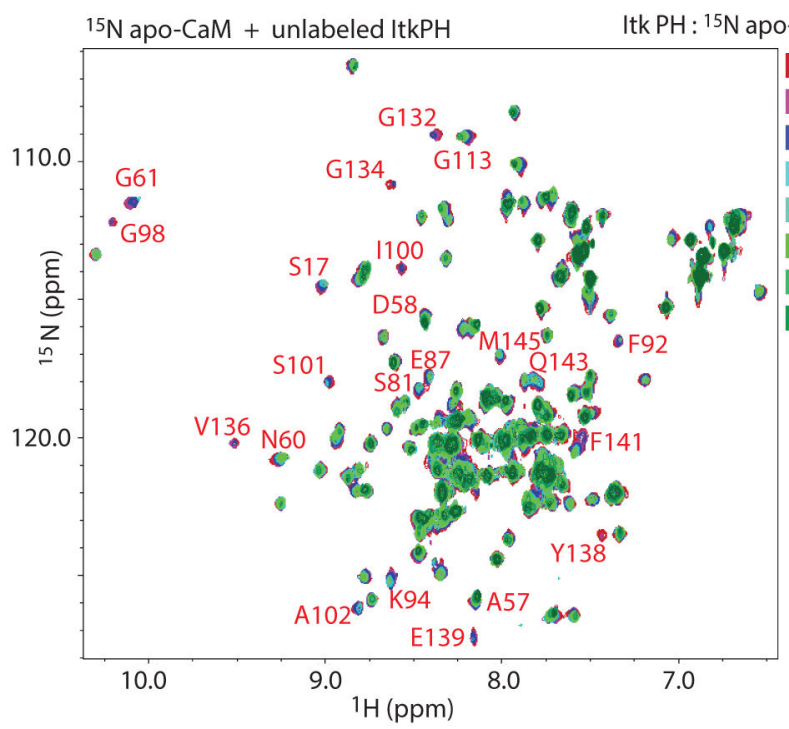

B

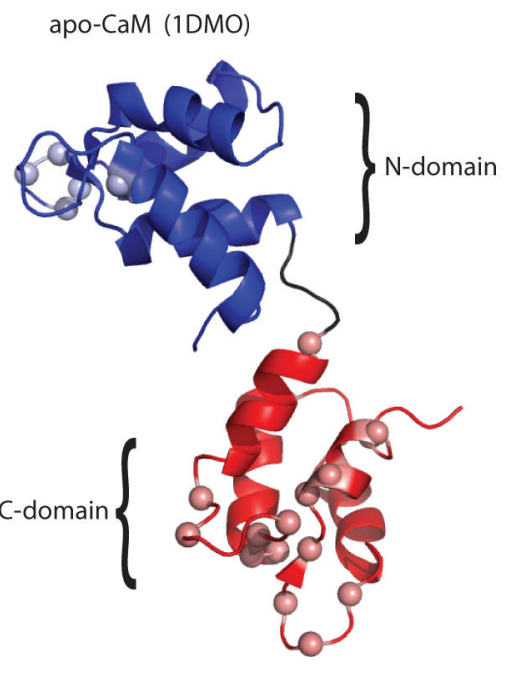

C

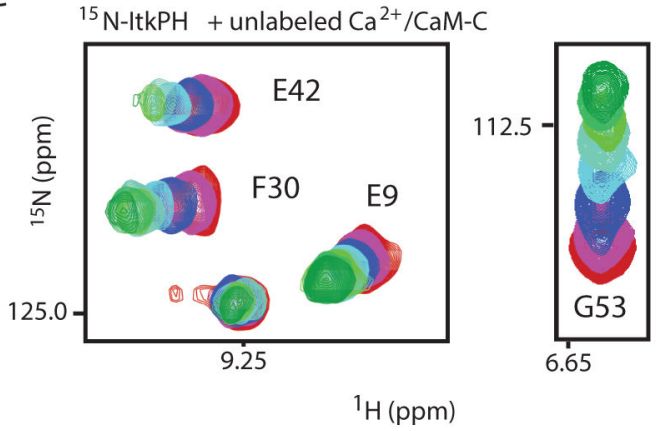

$\mathrm{D}$

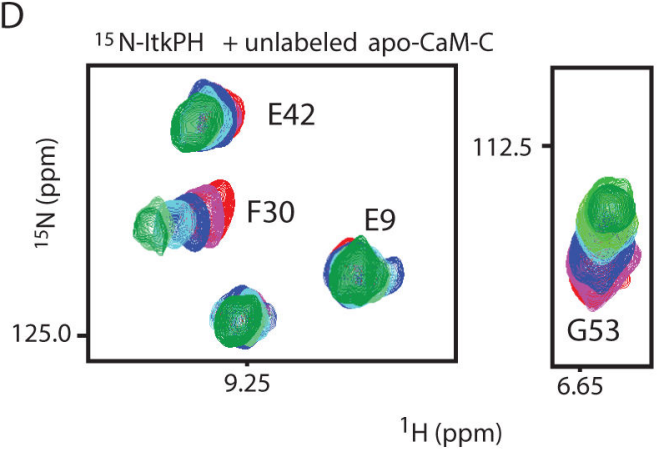

Fig 4. Binding of apo-CaM and the CaM C-domain to the Itk PH domain (A) Overlay of ${ }^{1} \mathrm{H}-{ }^{15} \mathrm{~N}-\mathrm{HSQC}$ spectra of $150 \mu \mathrm{M}{ }^{15} \mathrm{~N}$-labeled apo-CaM with increasing amounts of unlabeled Itk PH domain titrated at the indicated molar ratios (red to green); resonances that exhibit the largest spectral changes throughout the titration are labeled with the corresponding residue. (B) Residues exhibiting the most change mapped onto the structure of apo-CaM (PDB entry 1DMO) are represented as spheres. (C, D) Unlabeled $\mathrm{Ca}^{2+} / \mathrm{CaM}-\mathrm{C}$ (C) or apo-CaM-C (D) was titrated into $300 \mu \mathrm{M}{ }^{15} \mathrm{~N}$-labeled Itk PH domain at molar ratios identical to that used in Figure $2 \mathrm{C}$ ( $[\mathrm{CaM}]$ increases from red to green).

Selected regions of the HSQC spectra from the titration are shown; resonances showing the largest chemical shift changes are labeled in $(\mathrm{C})$ and the same resonances are indicated in (D). 
A

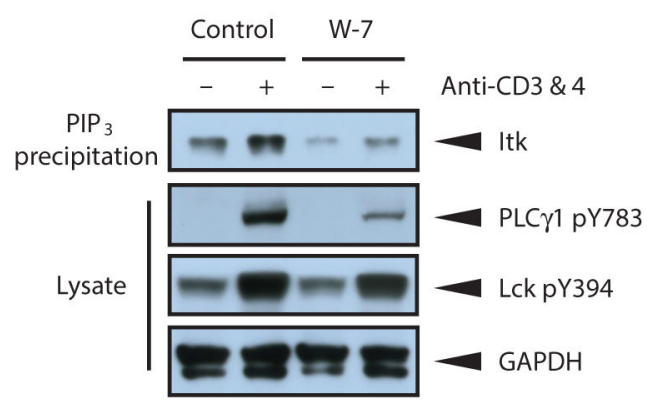

C

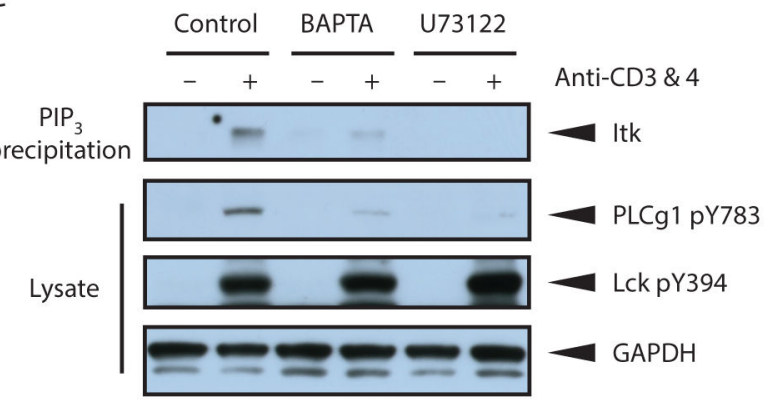

B
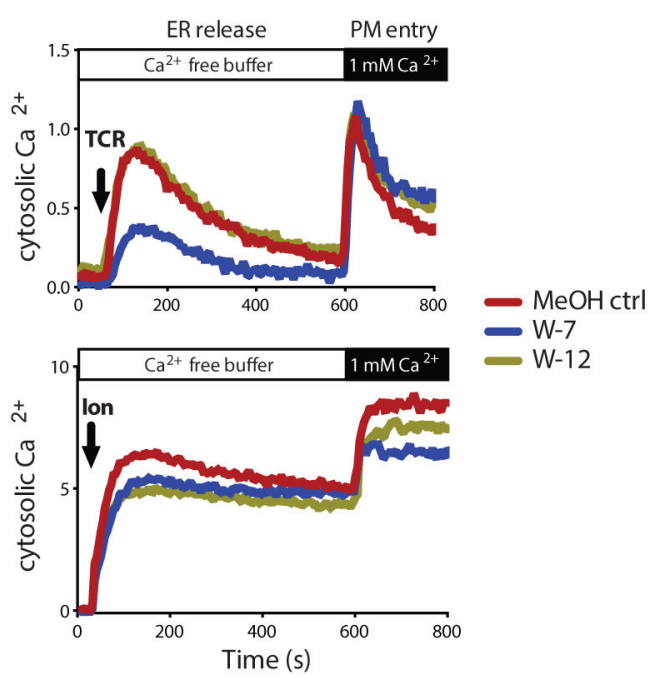

D

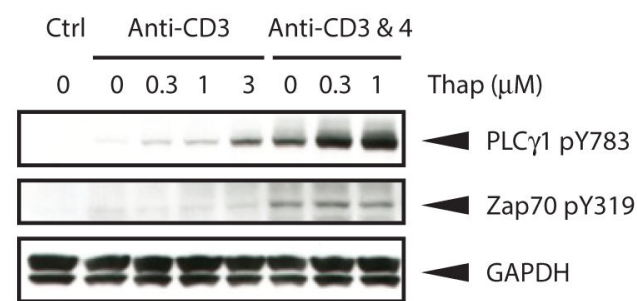

Fig 5. CaM promotes Itk activity and amplifies $\mathrm{Ca}^{2+}$ signaling in a positive feedback loop (A) Effect of CaM inhibition (W-7) on TCR-stimulated Itk binding to $\mathrm{PI}(3,4,5) \mathrm{P}_{3}$ and Itkmediated PLC $\gamma 1$ phosphorylation. Thymocytes were stimulated with antibodies recognizing the CD3 and CD4 (anti-CD3 \& 4) subunits of the TCR for 1 minute. TCR stimulation was

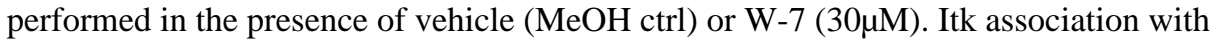
$\mathrm{PI}(3,4,5) \mathrm{P}_{3}$-coated beads and TCR-induced Lck and PLC $\gamma 1$ phosphorylation at the indicated residues was assessed by Western blot analysis. (B) TCR-induced or ionomycininduced cytosolic calcium accumulation in thymocytes exposed to vehicle ( $\mathrm{MeOH} \mathrm{ctrl})$, $\mathrm{W}-7$, or its inactive analog $\mathrm{W}-12 . \mathrm{Ca}^{2+}$ release from the ER was measured first in the absence of extracellular $\mathrm{Ca}^{2+}$ followed by $\mathrm{Ca}^{2+}$ entry through the plasma membrane (PM) by addition of $1 \mathrm{mM} \mathrm{Ca}^{2+}$ to the sample buffer. TCR stimulation was performed as in (A) in the presence or absence of W-7 $(30 \mu \mathrm{M})$ or W-12 $(30 \mu \mathrm{M})$. (C) Effect of depletion of $\mathrm{Ca}^{2+}$ from the ER by BAPTA-AM $(10 \mu \mathrm{M})$ and EGTA $(5 \mathrm{mM})$ or inhibition of PLC $\gamma 1$ catalytic activity $(\mathrm{U} 73122,5 \mu \mathrm{M})$ on Itk binding to $\mathrm{PI}(3,4,5) \mathrm{P}_{3}$ and subsequent Itk-mediated PLC $\gamma 1$ phosphorylation. Thymocytes were pretreated with indicated reagents for 30 minutes prior to stimulation with biotin-conjugated antibodies to CD3 and CD4 and streptavidin in warm PBS. Samples were separated by SDS-PAGE and analyzed by Western blot analysis with the indicated antibodies. (D) Effect of Thapsigargin (Thap)-mediated increase of cytosolic $\mathrm{Ca}^{2+}$ on Itk-dependent PLC $\gamma 1$ phosphorylation. Thymocytes were stimulated for 1 minute with biotin-conjugated antibody to CD3 and where indicated CD4 in the presence of $0-1$ $\mu \mathrm{M}$ Thap. Samples were separated by SDS-PAGE and analyzed by Western blot analysis with the indicated antibodies. All data are representative of 3 experiments. 
A

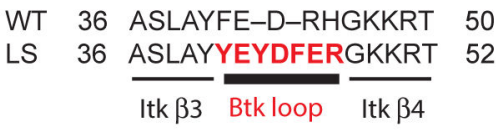

B

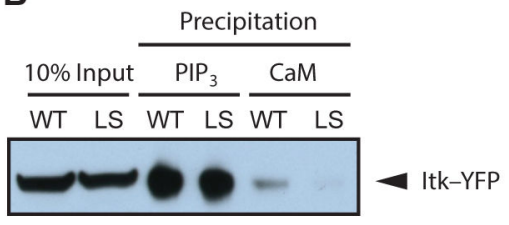

C
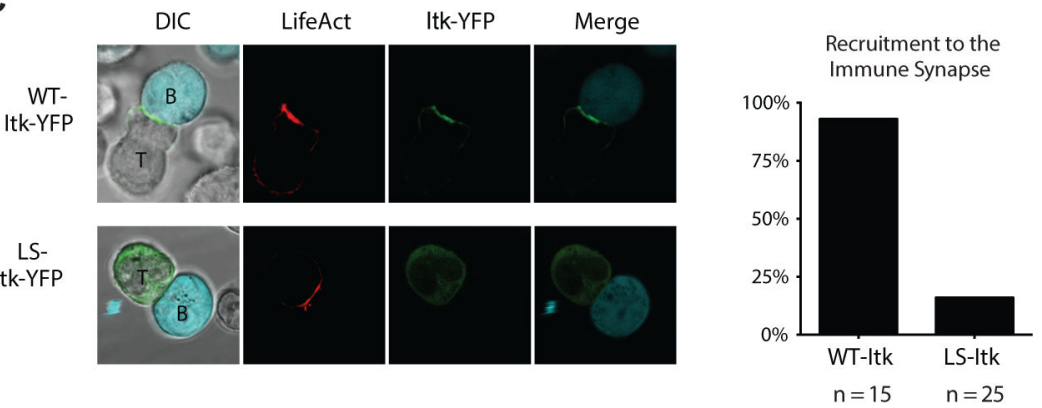

D Retroviral Reconstitution of $\mathrm{Itk}^{-1-} \mathrm{CD} 4 \mathrm{~T}$ cells
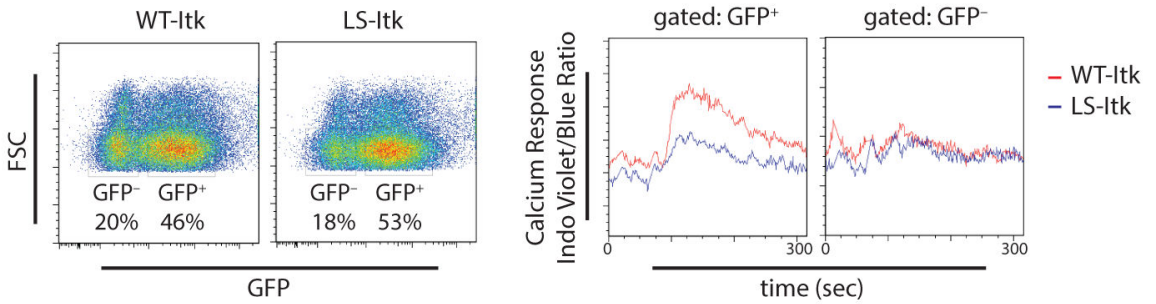

E

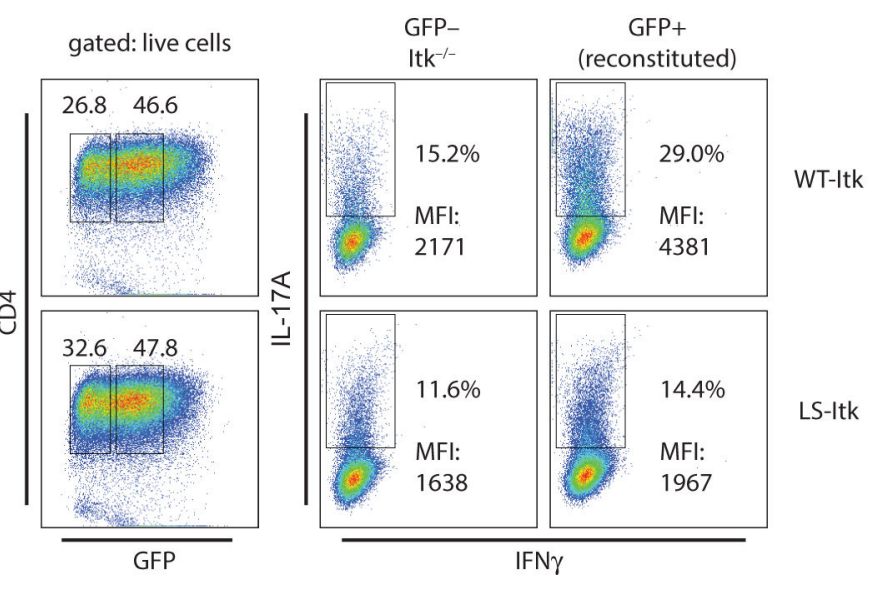

Fig. 6. A Itk mutant that cannot bind $\mathrm{CaM}$ is not recruited to the immune synapse in Jurkat $\mathrm{T}$ cells, and Itk-deficient CD4 $\mathrm{T}$ cells reconstituted with mutant exhibit reduced $\mathrm{Ca}^{2+}$ signaling and IL-17A production

(A) LS)-Itk was generated by replacing the 5 amino-acid $\beta 3 / \beta 4$ loop in Itk PH domain with the corresponding 7-amino acid loop from Btk. (B) Ability of LS-Itk to bind CaM and $\mathrm{PI}(3,4,5) \mathrm{P}_{3}$ in vitro. Cell lysates from HEK293 cells transfected with WT or LS-Itk were assessed for Itk binding to $\mathrm{Ca}^{2+} / \mathrm{CaM}$ or $\mathrm{PI}(3,4,5) \mathrm{P}_{3}$ by co-precipitation assay. Data are representative of 3 experiments. (C) Jurkat T cells expressing pRuby-LifeAct and WT- or LS-Itk-YFP fusion proteins were conjugated to Daudi (Turquoise-labeled) B cells in the presence of SEE super-antigen. Actin (red) and YFP (green) colocalization was assessed by 
confocal microscopy and quantified. (D) Primary Itk-deficient CD4 ${ }^{+} \mathrm{T}$ cells reconstituted with retrovirus expressing WT-Itk or LS-Itk and bicistronic GFP were loaded with Indo-1 and stimulated with antibodies against TCR subunits to detect changes in cytosolic $\mathrm{Ca}^{2+}$ amounts, which are plotted at the right as a ratio of Indo-1 Violet to Indo-1 Blue over time. $\mathrm{GFP}^{-}$and $\mathrm{GFP}^{+} \mathrm{T}$ cells represent nontransduced and transduced cells, respectively. Data are representative of 3 experiments. (E) Primary Itk-deficient $\mathrm{CD} 4^{+} \mathrm{T}$ cells reconstituted with retrovirus expressing WT- or LS-Itk were induced to differentiate into $\mathrm{T}_{\mathrm{H}} 17$ cells in culture and assessed for IL-17A and IFN $\gamma$ production. Left plots show the distribution of GFPnegative and -positive $\mathrm{CD} 4^{+} \mathrm{T}$ cells with GFP gates for middle and right plots indicated by the boxed regions. Middle and right plots show the abundance of IL-17A-positive cells in GFP-negative (non-reconstituted Itk $^{-/}$cell) and GFP-positive (WT-Itk- or LS-Itkreconstituted $\mathrm{Itk}^{-/-}$cell) populations respectively that produce low amounts of IFN $\gamma$, thereby defining the percent of $\mathrm{T}_{\mathrm{H}} 17$ cells. Data are representative of 3 experiments. DIC,

Differential interference contrast; FSC, Foward scatter; MFI, Mean fluorescence intensity 
A

Binding Prediction for $\mathrm{PH}$ domains

to Calmodulin ( 236 total)

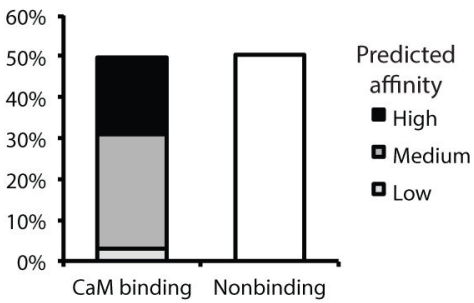

B

CaM Precipitation
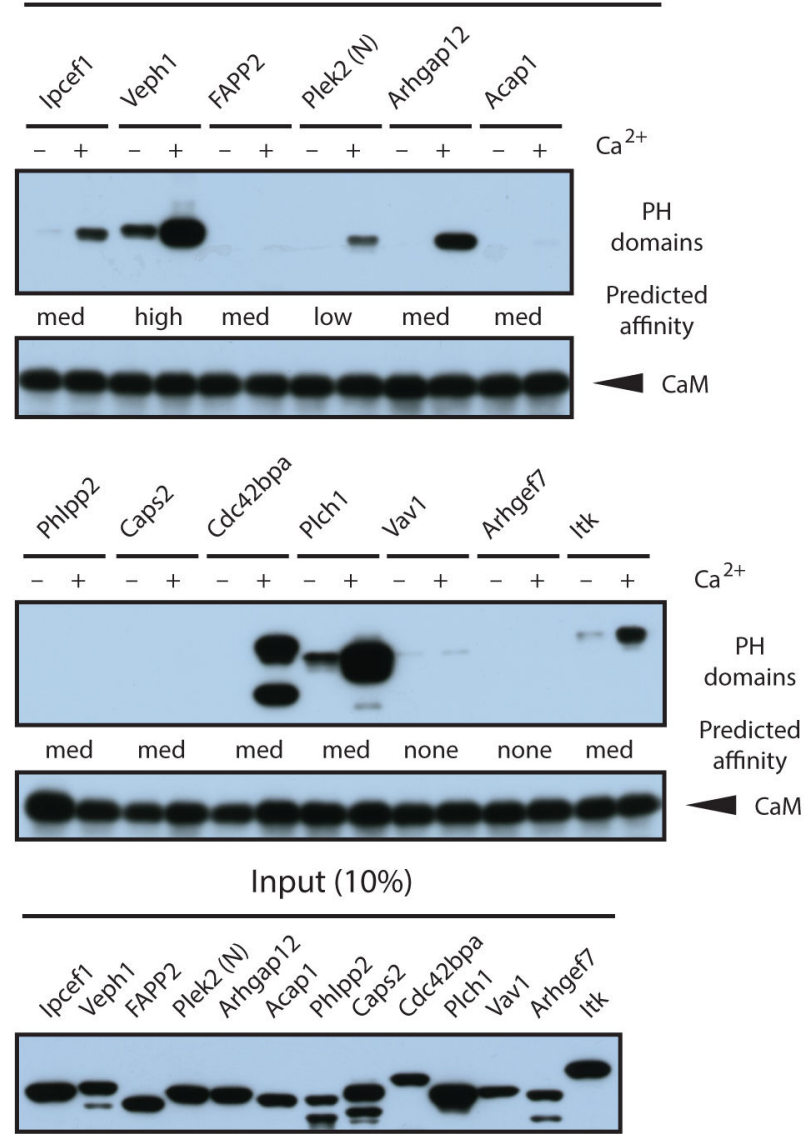

Fig. 7. CaM is a putative protein ligand for multiple $\mathbf{P H}$ domains

(A) Calmodulin target prediction for mouse PH domain-containing proteins annotated in Uniprot predicts that $>50 \%$ of $\mathrm{PH}$ domains bind CaM. Predicted relative affinities are based on the number of consecutive amino acids (aa) scoring 8 in the algorithm: low (1-7 consecutive aa), medium (8-14 aa), and high affinity (15-21 aa). See table S3 for the results of the analysis of the $236 \mathrm{PH}$ domains tested (B) PH domains with indicated predicted affinities and the $\mathrm{PH}$ domain of Itk were assessed in precipitation assays with apo-CaM and $\mathrm{Ca}^{2+} / \mathrm{CaM}\left(+/-\mathrm{Ca}^{2+}\right)$. For some PH domain-YFP fusions, smaller fragments likely derived from internal translational start sites were observed. 